\title{
Two competing Paleomagnetic directions in the Late Vendian: New data for the SW Region of the Siberian Platform
}

\author{
A. V. Shatsillo ${ }^{1}$, A. N. Didenko ${ }^{2}$, and V. E. Pavlov ${ }^{1}$ \\ Received 15 December 2004; revised 10 February 2005; accepted 21 May 2005; published 24 September 2005.
}

[1] New paleomagnetic data have been obtained for the Late Vendian sedimentary rocks of the East Sayan and Southwest Baikal regions in the southwest of the Siberian platform. Two substantially different paleomagnetic components are isolated within the investigated stratigraphic interval in all objects of study. The prefolding age of these components, as well as their difference from all of the known Phanerozoic paleomagnetic directions of the Siberian platform, indicate the almost simultaneous formation of the respective magnetization components during the earliest stages of the existence of these rocks. The angular distance between the paleomagnetic poles calculated for these components is about $45^{\circ}$. The analysis of the World Paleomagnetic Database shows that the presence of the discordant paleomagnetic directions in the Vendian-Early Cambrian rocks is characteristic not only of the Siberian objects but is also manifested in other continents and, hence, can be considered as the phenomenon of the planetary scale. We reckon that this fact can be explained by the anomalous behavior of the magnetic field of the Earth around the Precambrian-Cambrian boundary. In this paper we suggest a model describing the "geometry" of the Earth magnetic field in the Late Vendian-Early Cambrian, which allows one to explain the observed pattern of the paleomagnetic record. INDEX TERMS: 1500

Geomagnetism and Paleomagnetism; 1527 Geomagnetism and Paleomagnetism: Paleomagnetism applied to geologic processes; 9320 Geographic Location: Asia; KEYWORDS: paleomagnetism, Vendian, Cambrian, Siberian platform, anomalous geomagnetic field behavior.

Citation: Shatsillo, A. V., A. N. Didenko, and V. E. Pavlov (2005), Two competing Paleomagnetic directions in the Late Vendian: New data for the SW Region of the Siberian Platform, Russ. J. Earth. Sci., 7, ES4002, doi:10.2205/2004ES000169.

\section{Introduction}

[2] By the present time about 30 paleomagnetic determinations have been obtained for the Vendian rocks of the Siberian Platform. The paleomagnetic studies of the Vendian rocks in Siberia were initiated in the early 1970s and embraced almost all of the regions where these rocks outcrop at the ground surface. These regions include the peripheral part of the platform in its southwestern area, its northeastern area (Kharaulakh Mts.), the Patom Highland, the Udzha and Olenek uplifts, the Uchur-Maya region, and other areas [Gurevich, 1981, 1983; Komissarova, 1983, 1984, 1991; Komissarova and Osipova, 1986; Konstantinov, 1998; Kravchinsky et al., 2001; Pavlov and Petrov, 1997; Pavlov et

\footnotetext{
${ }^{1}$ Institute of Physics of the Earth, Moscow, Russia

${ }^{2}$ Geological Institute, Russian Academy of Sciences, Moscow, Russia
}

Copyright 2005 by the Russian Journal of Earth Sciences. ISSN: 1681-1208 (online) al., 2004; Pisarevsky et al., 2000; Rodionov, 1984; Shatsillo et al., 2001]. However, in spite of the numerous studies that have been carried out for more than thirty years, the position of the Vendian paleomagnetic pole of Siberia has not been determined unambiguously. Almost each new paleomagnetic determination is an alternative to the previous ones, the distribution of the paleomagnetic poles showing a scatter of $120^{\circ}$ in longitude and $60^{\circ}$ in latitude [Shatsillo et al., 2001]. Attempts of correlating the paleomagnetic data with the age levels of the Vendian System for the purpose of identifying any significant movement of Siberia in Vendian time, explaining observed poles scattering, also failed. It should be noted that both the younger Paleozoic rocks (beginning from the Middle Cambrian), and the older Middle and Late Riphean rocks of the Siberian platform fairly often show a distinct paleomagnetic signal, the paleomagnetic determinations available for the rocks of the same age from far-spaced regions showing good agreement.

[3] The significant number of the paleomagnetic determinations available for the Vendian rocks of Siberia does not meet the criteria of paleomagnetic reliability and formally 


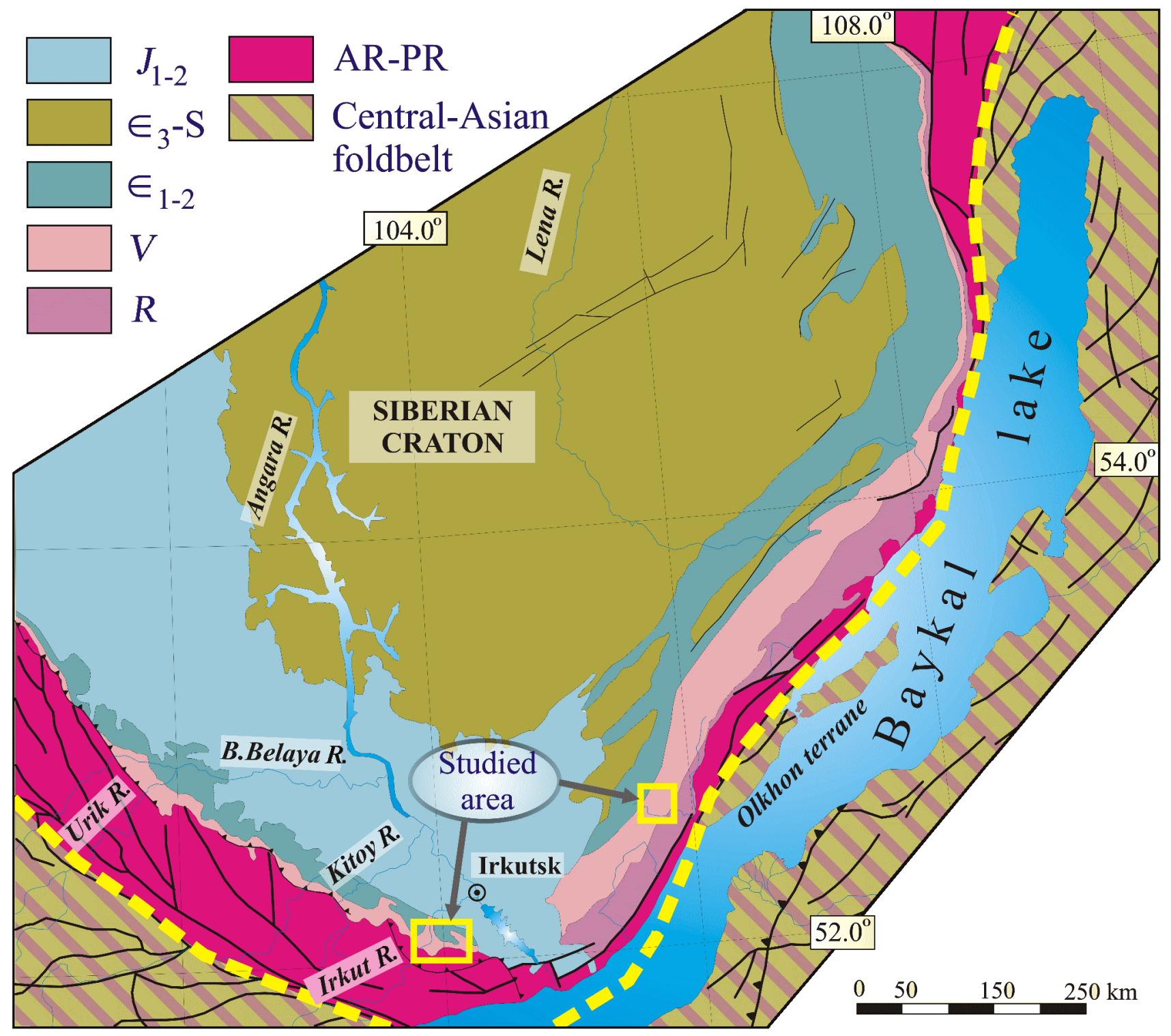

Figure 1. Sketch geological map of the SW Siberian Platform.

can be discarded. However, even the highly rigid selection of the data accumulated does not allow one to select any preferential direction.

[4] In the recent years a number of new papers has been published on the paleomagnetism of the Vendian rocks of Siberia; the data they reported had been obtained in accordance with the modern requirements for methods and instruments (detailed magnetic cleaning, component analysis, etc.) [Konstantinov, 1998; Kravchinsky et al., 2001; Pisarevsky et al., 2000]. However, even these paleomagnetic determinations have a number of drawbacks. First, these determinations were obtained for far-spaced objects from different, not always clearly determined stratigraphic levels. In most cases no tests were made to verify the primary character of the paleomagnetic directions obtained. One of the best determinations (in paleomagnetic aspect), obtained for the Baikal region [Pisarevsky et al., 2000], cannot apparently be classified as a "Siberian" pole, since the study object resides in the zone of intensive Paleozoic deformation and in accordance with the data of structural-geological researches [Aleksandrov et al., 2001; Malykh, 1997] has an allochthonous position.

[5] Uncertainty in locating poles for the PrecambrianPhanerozoic boundary has been indicated also for other old ancient platforms and is still a matter of hot discussion [Meert, 1999; Torsvik et al., 1998], to mention but a few.

[6] The study reported in this paper was an attempt to investigate the single Vendian stratigraphic level in the volume of the Nemakit-Daldynian Stage in the remote sections of the Southwest Baikal and East Sayan regions (Figure 1). 


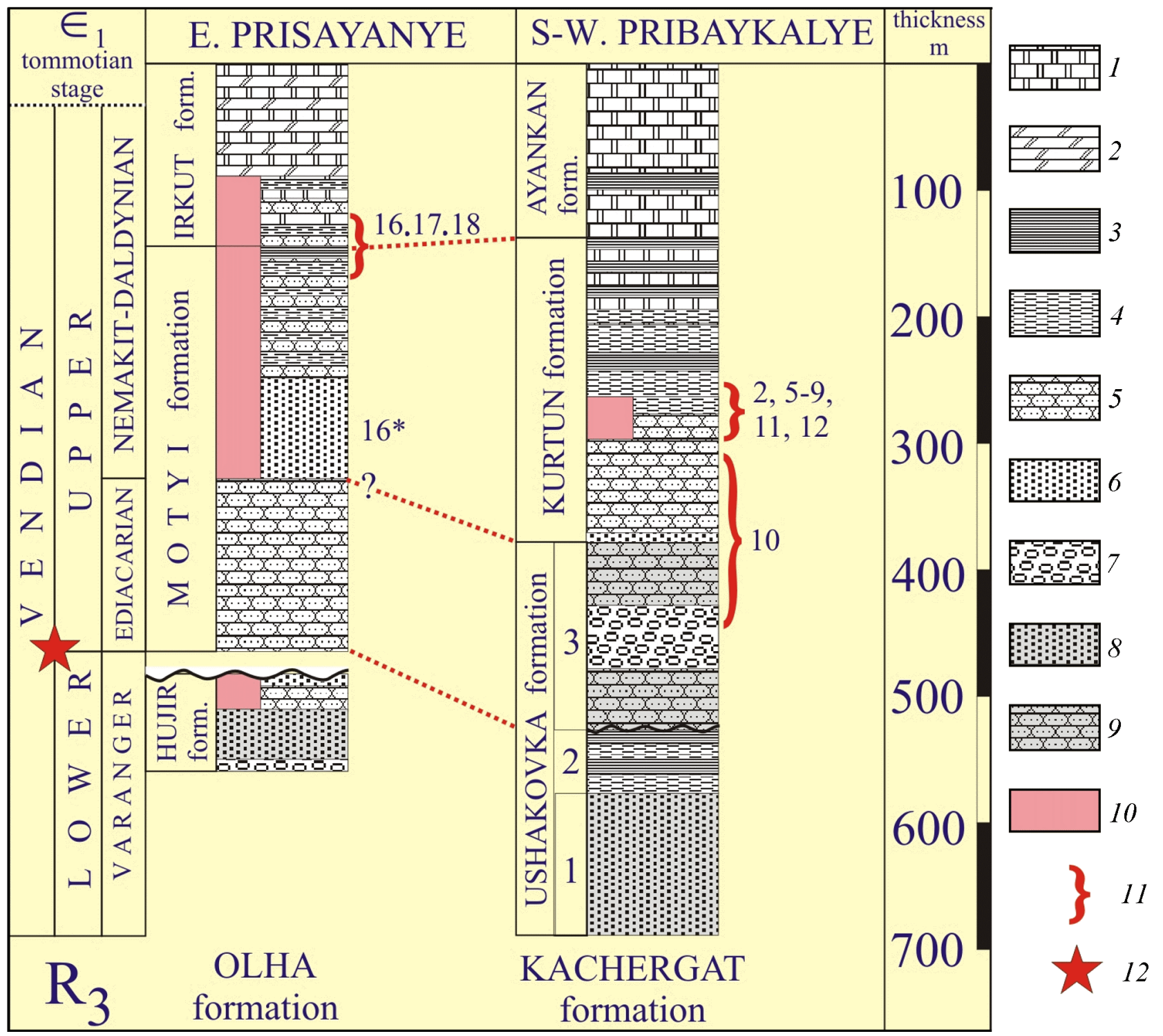

Figure 2. Lithostratigraphic column and schema of stratigraphic subdivision od sections studied [after Kochnev, 2002]: (1) dolomite; (2) dolomitic marl; (3) argillite; (4) siltstone; (5) fine- to medium-grained sandstone; (6) coarse-grained sandstone and gravelite; (7) conglomerate; (8) polymictic coarse-grained sandstone and gravelstone; (9) polymictic fine- and medium-grained sandstone; (10) red rocks; (11) intervals of study, the figures denote site nos.; (12) the lower boundary of the Nemakit-Daldynian stage (see the text). The mark $16^{*}$ denotes the rock interval investigated by Kravchinsky et al. [2001].

In tectonic respect, the sections considered belong to sedimentary cover of the Siberian platform.

\section{Geology and Age}

[7] The Vendian rocks of the southwestern margin of the Siberian Platform [Khomentovsky et al., 1972; Kochnev, 2002] occur in the present-day erosion cut as a narrow band of outcropping rocks surrounding the Siberian Craton along its periphery (Figure 1). Generally, the Vendian rocks inherited the structure of the older Riphean troughs, rest- ing on the Riphean rocks with a regional unconformity. The Vendian rocks are conformably overlapped by the carbonate deposits with Lower Cambrian fauna. As follows from the traditional stratigraphic scheme (see Figure 2), the Vendian rocks of this region occur as a thick sedimentation cycle, which begins with a terrigenous molasse formation (with the size of the clastic material ranging from conglomerate to argillite), represented by the Khuzhir, Ushakovka, Moty, and Kurtun formations, and terminates as a terrigenous-carbonate, mainly dolomite, sequence of the Irkut and Ayanka formations totaling $600-1500 \mathrm{~m}$ in thickness.

[8] The areas discussed in this paper vary greatly in their 


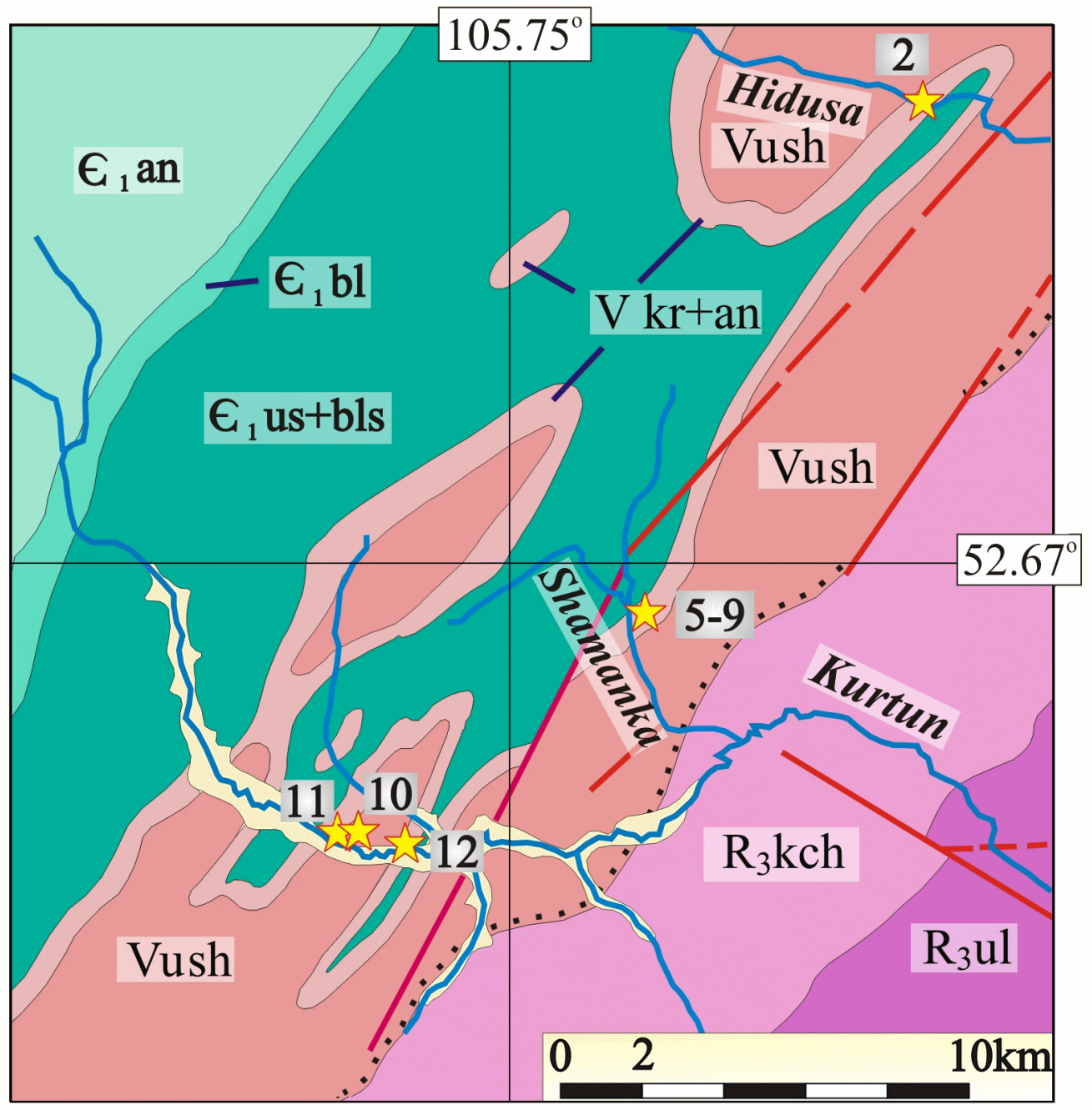

Figure 3. Schematic geological map of the study area in the southwest Baikal region. The indices denoting the rock formations: (an) Angara Fm; (bl) Bulai Fm; (us+bls) Usolie and Belsk Fms, undifferentiated, (kr+an) Kurtun and Ayankan Fms, undifferentiated, (ush) Ushakovka Fm, (kch) Kachergat Fm., (ul) Uluntui Fm; the asterisks and numbers denote the studied outcrops.

tectonic histories. The Vendian rocks of the Sayan region are almost undeformed and compose gentle monoclines dipping toward the platform at angles of a few degrees. At the same time the Vendian rocks of the Baikal region are deformed to steep and long linear folds of the northeast strike, broken by faults of the same orientation. It is believed that this folding was caused by Caledonian events which expressed themselves in the collision of the Olkhon Terrain and the Siberian Platform and can be dated as Early Ordovician, as follows from the latest geochronologic data [Rozen and Fedorovsky, 2001] for the isotopic rejuvenation of the basement rocks.

[9] Views differ as to the volume of the Vendian rocks in this region, the fossil remains proving only their upper boundary (by the first findings of Cambrian-Tommotian forms) [Kochnev, 2002; Rozanova et al., 1992]. As follows from conventional views [Khomentovsky et al., 1972], the main criterion for drawing a boundary between the Vendian and Baikalian (Late Riphean) rocks is to proceed from the events of geologic history. On this basis, judging by the broadening of the sedimentation basin, associated with a change in the structural style, the lower Vendian boundary is correlated with the bases of the Ushakovka (Baikal region) and the Khuzhir (Sayan region) formations [Kochnev, 2002; Khomentovsky and Postnikov, 2001] (Figure 2). Very important for the Vendian stratigraphy of the region were the Ediakarian fossils (Baicalina sessilis Sok., Cylindrichnus sp., and Pteridinium sp.) found in the rocks of the Late Ushakovka member of the Ushakovka Formation [Sokolov, 1975]. On this basis these rocks and their stratigraphic analogs can be dated 560-580 Ma. The upper member of the Kurtun Formation was found to contain the skeletonless fauna represented by Paleolina aff. Evenkiane Sokolov [Khomentovsky et al., 1972], and vendotenium flora [Sokolov, 1975]. The rocks of the Ayankan Formation are known for their complete assemblage of Vendian stromatolites: Jurusania sibirica (Yak.), Linella simica (Kryl.), Boxonia allachjunica (Kom. et Semikh.), and Colleniella singularis Kom. [Korolyuk and Sidorov, 1969]. Also available for the 
rocks of the Kurtun Formation are K-Ar ages of 606 Ma and $609 \mathrm{Ma}$ of glauconite [Anisimova and Titorenko, 1976], yet they are now considered to be obsolete.

[10] Because of the scarcity of fauna remains in the Vendian rocks of the study region, the rock sequences are compared and correlated on the basis of their lithologies [Khomentovsky et al., 1972; Kochnev, 2002].

[11] There is a different view for the volume of the Vendian rocks in the southwest of the Siberian Platform, as well as for the position of their lower boundary and their subdivision, which is accepted in present paper. Yu. K. Sovetov [Sovetov, 2002a, 2002b] discovered diamictite boulders showing the typical lithologic features of tillite at the base of the Marnia Formation (Oselok Series) in the Uda River area (Prisayanie). He discovered similar rocks in some other stratigraphic analogs of the Oselkovo Series. On this basis they were combined into one tillite horizon corresponding to the Varangerian glaciation, corresponding in terms of its volume to the Lower Vendian [Sokolov, 1997]. According to these data, the Ediacarian+Nemakit-Daldynian stages of the conventional Vendian must correspond to the NemakitDaldynian Stage (Figure 2).

[12] More arguments are being accumulated each year in favor of the larger stratigraphic volume of the Siberian Vendian rocks, at the expense of the Baikalian rocks. The isotopic and geochemical studies $\left(\delta^{13} \mathrm{C}\right.$ and $\left.{ }^{87} \mathrm{Sr} /{ }^{86} \mathrm{Sr}\right)$ using the rocks of the Baikalian Series from a stratotype area, compared with the "reference" curves available for the Late Precambrian, suggest the Vendian (pre-Nemakit-Daldynian) age of these rocks [Letnikova et al., 2004].

[13] In addition, B. B. Kochnev (Institute of Geophysics and Petroleum Geology, Novosibirsk, unpublished data) reported in the lower member of Ust-Tagul formation, where the base of Ediacarian was traced according to conventional schema, the traces of the living activity of the organisms, identified by D. V. Grazhdankin (Paleontological Institute, Russian Academy of Science) as Treptichnus pedum, a typi-

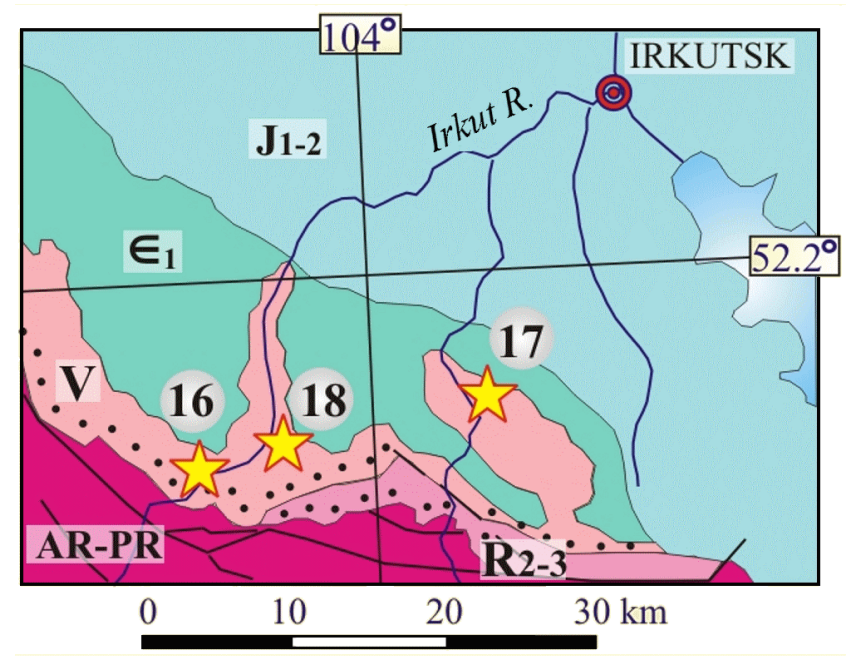

Figure 4. Schematic geological map of the East Sayan area of study, the asterisks and numbers denoting the studied outcrops. cal fossil for the base of the Nemakit-Daldynian Stage.

[14] Hence, on the basis of the recent data, the objects of this study (see below) can be attributed to the NemakitDaldynian Stage of the Vendian.

[15] Another point that calls for a study is the argued position of a boundary between the Vendian and the Lower Cambrian. Most of the Russian geologists include the Nemakit-Daldynian Stage into the Vendian System [Khomentovsky, 2000; Khomentovsky et al., 1998; Kochnev, 2002; Rozanov et al., 1992, 1997; Sokolov, 1997], to name but a few. At the same time, foreign geologists place the lower boundary of the Cambrian at the base of the Nemakit-Daldynian Stage [Brasier et al., 1994; Harland et al., 1990; Landing, 1994; Tucker and McKerrow, 1995]. Thus, presently, it is more correct to classify the NemakitDaldyn stage as a Vendian-Lower Cambrian transition unit.

\section{Objects of Study}

\section{Southwest Baikal Region}

[16] Samples for the paleomagnetic study were collected in the drainage basin of the Kurtun River and its tributaries, known as the Shamanka and Khidusa Rivers (Figure 3). The Vendian rocks are deformed there into a complex syncline of a NE strike, grading toward the center of the platform into an undeformed, subhorizontal platform cover.

[17] No large faults that might have caused any displacements of the study rocks relative to the platform area have been recorded in the survey scale of 200 000. Samples for the paleomagnetic study were collected from the thin variegated member of the Kurtun Formation (ranging from $8 \mathrm{~m}$ to $40 \mathrm{~m}$ in thickness) composed of red and green feldspar-quartz sandstones (sampling sites 2, 5-9, 11, and $12-125$ samples), and also from the top of the Ushakovka to the bottom of the Kurtun Formation, represented by light greenish-gray polymictic and quartz sandstones (sampling site 10 where 60 samples were collected from about $200 \mathrm{~m}$ of the rock sequence) (Figure 2). In the Baikal region samples were collected from the rocks of the Ushakovka and Kurtun formations along the Kolesma Derevenskaya River and in the area of the Goryachii Klyuch Village. However, no representative paleomagnetic information was obtained there, and this object of study will not be discussed here.

\section{East Sayan Region}

[18] The object of study here was the transitional part of the Moty and Irkut formations in the stratotype key section along the Irkut River, namely, at the Shaman Mountain (Site 16), where 27 samples were collected along about $30 \mathrm{~m}$ of the rock sequence, and in the area of the Moty Settlement (Site 18), where 33 samples were collected along about $40 \mathrm{~m}$ of the rock sequence, the rocks being mainly red quartz sandstone and siltstone (see Figure 2 and Figure 4). The Vendian rocks, composing the studied section along the Irkut 

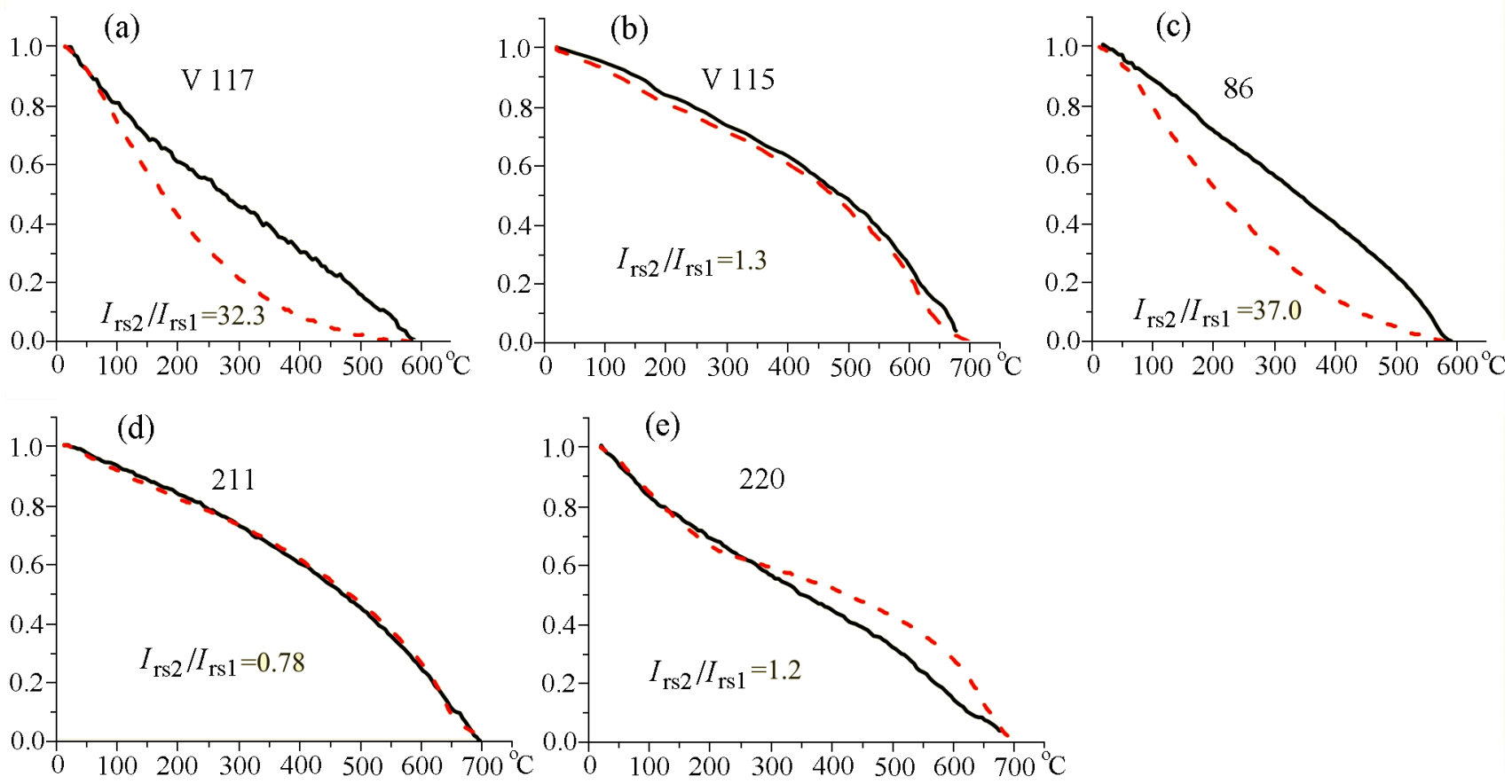

Figure 5. Curves of remanent saturation magnetization vs temperature for the rocks of (a-b) Kurtum Fm., (c) Ushakovka Fm., (d) transition from the Moty to Irkut Fms., (e) Irkut Formation. The red broken line shows the results of the second heating.

River, are nearly horizontal, showing insignificant variations in their dips and strikes. 15 samples of pink-grey quartz sandstones were also collected at the bank of the Olkha River (Site 17) from a small outcrop of the Irkut Formation rocks, located at anticline flank, dipping to the north at $19^{\circ}$ to $35^{\circ}$.

\section{Methods of Study}

[19] The rock samples were processed at the paleomagnetic laboratories of the Institute of Physics of the Earth (IPE), Russian Academy of Sciences (Moscow), Institut de Physic du Globe (IPGP, Paris), and All-Russian Geological Institute (VSEGEI, St. Petersburg). Remanent magnetization was measured using the JR-4, JR-5, and 2-G Enterprise instruments magnetometers, magnetic susceptibility was measured using a KLY-2 kappa-bridge. All samples were subjected to detailed temperature cleaning up to $680^{\circ} \mathrm{C}$, the number of steps being not less than 16. All laboratory procedures were performed in the rooms protected from the outer magnetic field. Some samples of the Ushakovka Series rocks were processed using a combined thermal and alternate-field cleaning. The efficiency of this method was found to be low in the case of the rocks concerned. The behavior of the remanent magnetization vectors in the course of magnetic cleaning was analyzed using a component analysis following the conventional procedure using the computer programs written by R. J. Enkin and S. V. Shipunov [Bazhenov and Shipunov, 1991; Enkin, 1990, 1994; Shipunov, 1995; Shipunov and Muraviev, 2000], to name but a few.

\section{Magnetic Cleaning Results}

\section{Southwest Baikal Region}

[20] Kurtun Formation (Sites 2, 5-9, 11, and 12). The natural remanent magnetization (NRM) of the variegated sandstones of the Kurtun Formation varies from $0.2 \mathrm{~mA} \mathrm{~m}^{-1}$ to $4.8 \mathrm{~mA} \mathrm{~m}^{-1}$, averaging $1.6 \mathrm{~mA} \mathrm{~m}^{-1}$, the values of magnetic susceptibility varying from 93 to $340 \times 10^{-6}$ SI units, the average value being $195 \times 10^{-6} \mathrm{SI}$. As follows from the curves of the remanent saturation magnetization vs. temperature $I_{\mathrm{rs}}(T)$ (Figure $5 \mathrm{a}$ and b), the magnetic carriers of the studied rocks are hematite and magnetite. As a rule, the $I_{\mathrm{rs}}$ values grow notably (in some cases by more than an order of magnitude) after the first heating. Magnetic susceptibility also grew with heating, averaging $86 \%$ at the last cleaning steps $\left(T=560-680^{\circ} \mathrm{C}\right)$. This seems to be associated with magnetite formation during the oxidation of pyrite, the presence of which was recorded in the rocks of the Kurtun and Ushakovka formations [Pisarchik, 1963]. It should be noted that because of the low significance of Sites 2, 5-9, and 11 and of their geographic proximity, we combined them with Site 12 (Figure 3), which is the stratotype of the Kurtun Formation, and is more representative, both in the number of the samples available, and in the better exposure and larger thickness of the rocks. The magnetic cleaning of studied samples of Kurtun formation allowed to isolate (in addition to the laboratory viscous component) three magnetization components, which produce three fairly distinct clusters in the stereogram: 
(a)

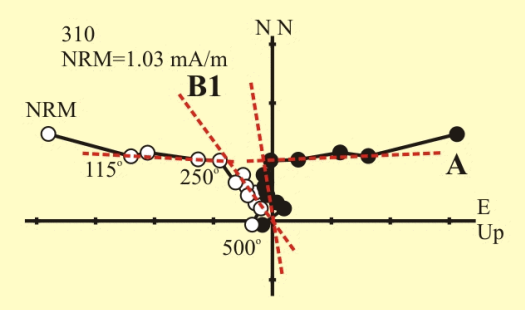

(c)

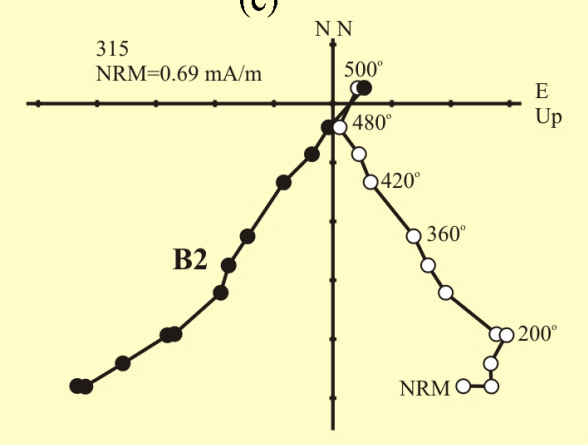

(f)

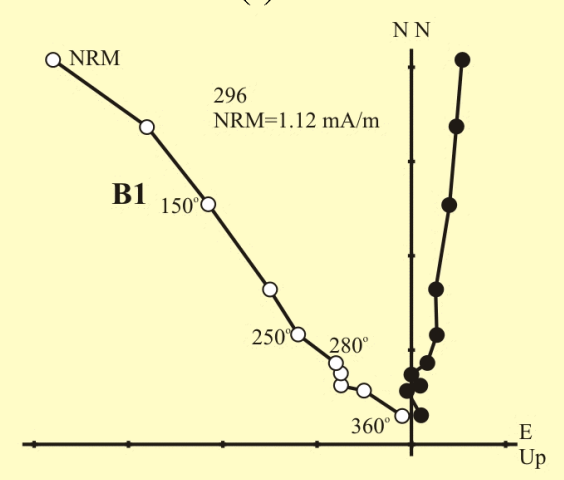

(b)

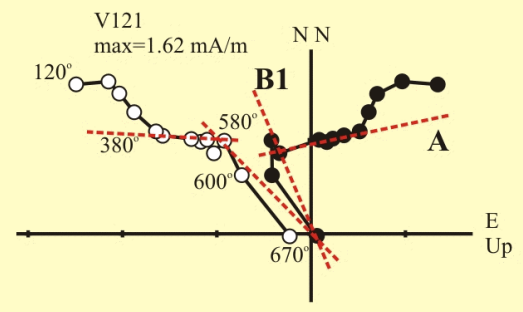

(d)
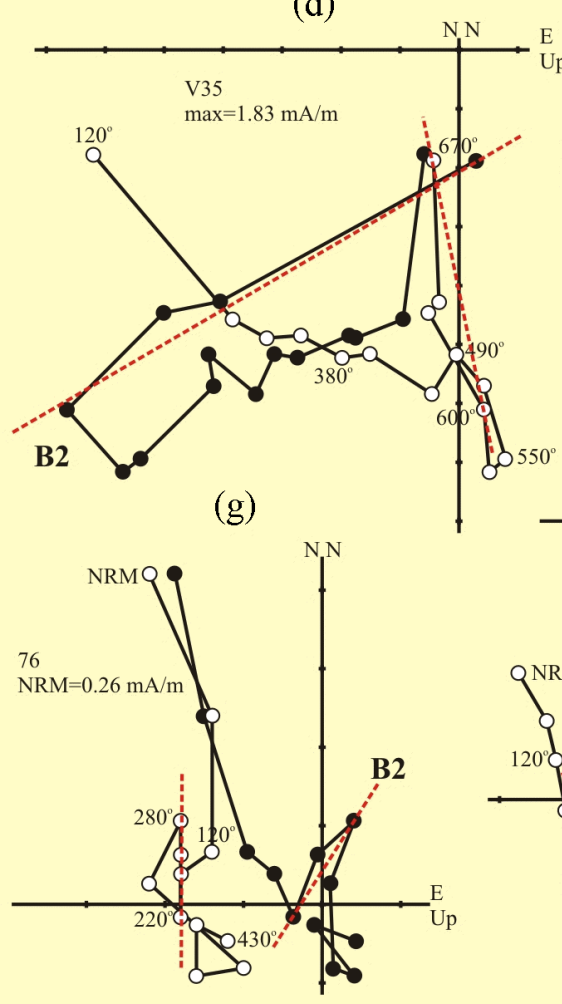

(e)

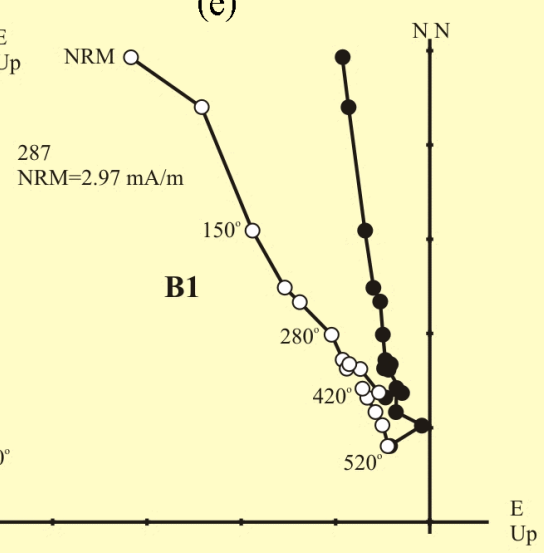

(h)

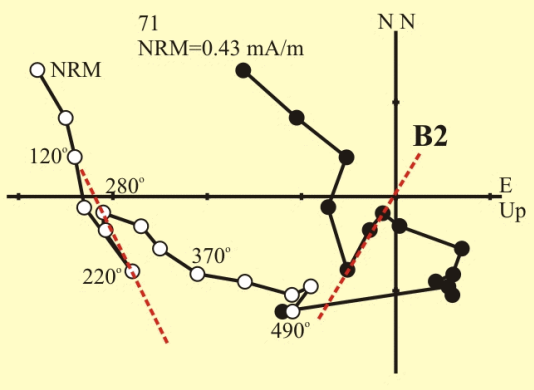

Figure 6. Typical Zijderveld diagrams for the rocks of the SW Baikal region: (a-d) Kurtun Formation, $(\mathrm{e}-\mathrm{h})$ Ushakovka Formation. The solid circles show the projections of the magnetization vectors onto the horizontal plane; the open circles show the same onto the vertical plane. All diagrams are given in the stratigraphic system of the coordinates.

[21] (1) the intermediate component $\mathrm{A}$, recorded in the temperature range of $100^{\circ} \mathrm{C}$ to $200-350^{\circ} \mathrm{C}$ and found in most of the study samples. In some cases $\mathrm{A}$ is the only component found in the sample, being destroyed at the temperatures close to $T_{\mathrm{c}}$ (Curie temperature) of magnetite (Figure 6a and b);

[22] (2) the high-temperature B1 component (Figure 6a and $\mathrm{b}$ ), found roughly in $30 \%$ of the study samples, is destroyed in a temperature range of $420-680^{\circ} \mathrm{C}$ (up to the $T_{\mathrm{c}}$ for magnetite and hematite);

[23] (3) the high-temperature B2 component distinguished in the temperature range of $300-520^{\circ} \mathrm{C}$ to $480-680^{\circ} \mathrm{C}$ in $15 \%$ of the samples, up to the $T_{\mathrm{c}}$ of magnetite and hematite (see c and $d$ in Figure 6);

[24] The A component is a single-polarity one and has a post-folding age (see Figure 7 and Table 1). B1 component is a pre-folding, predominantly single-polarity component (Figure 7 and Table 1), although in some samples it has a reversed polarity.

[25] We failed to estimate the time of the B2 component formation relative to the folding event using all kinds of tests, apparently, because of a "noise signal" and, possibly, because of the small number of samples for which it was obtained (Figure 7, Table 1). Note that the B2 component is a bipo- 

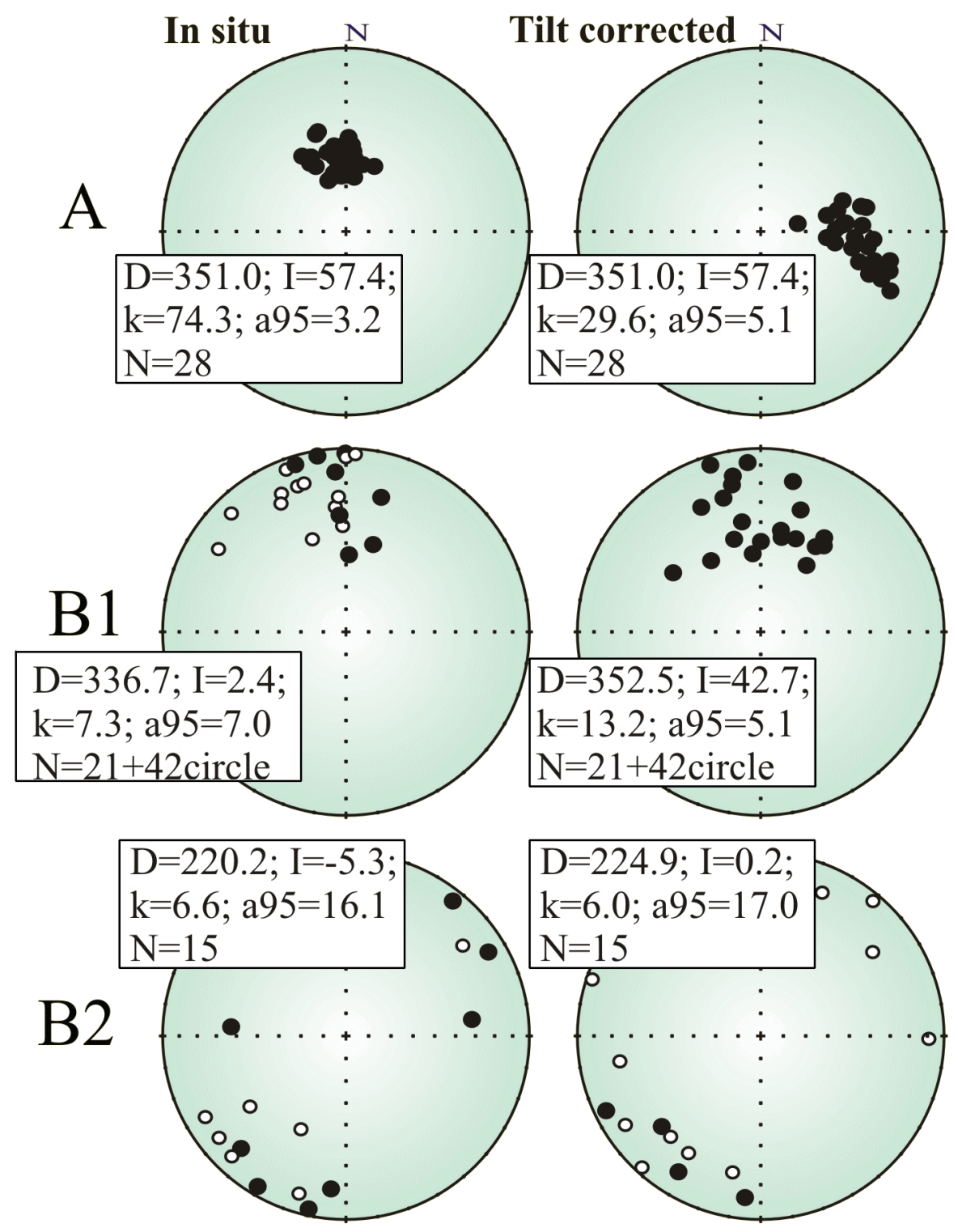

Figure 7. The distribution of the vectors of the A, B1, and B2 components of the Kurtun Formation in the southwest Baikal region. The solid circles denote the projection on the lower hemisphere, the open ones,onthe upper.

lar one, and its direction does not coincide with any of the known younger ones.

[26] Ushakovka Formation (Site 10). The polymictic and quartz sandstones from the top of the Ushakovka to the bottom of the Kurtun Formation showed the following magnetic parameters: NRM ranging from $0.1 \mathrm{~mA} \mathrm{~m}^{-1}$ to $9.0 \mathrm{~mA} \mathrm{~m}^{-1}$, the average value being $1.8 \mathrm{~mA} \mathrm{~m}^{-1}$; magnetic susceptibility value ranging from 140 to $530 \times 10^{-6} \mathrm{Si}$ units, the average value being $309 \times 10^{-6}$ SI units. The $I_{\mathrm{rs}}(T)$ curves (Figure $5 \mathrm{c}$ ) suggest the presence of magnetite as a magnetization carrier. Generally, most of NRM (>80\%) is removed during heating to $450^{\circ} \mathrm{C}$. At higher temperatures the NRM vector varies chaotically in its direction, the magnetic susceptibility value begins to grow up to $50 \%$ at $T=500^{\circ} \mathrm{C}$, and the paleomagnetic signal cannot be interpreted.

[27] Like in the case of the variegated rocks of the Kurtun Formation, strong parasitic remagnetization is observed which is caused by the newly formed magnetite.

[28] Magnetic cleaning revealed three magnetization components:

[29] (1) the low-temperature $\left(<200^{\circ} \mathrm{C}\right)$ postfolding component, close to the modern magnetic field of the Earth in direction (not discussed here);

[30] (2) the high-temperature prefolding B1 component isolated in the temperature range of $250-500^{\circ} \mathrm{C}$ and having one polarity (Figure 6e, f; Figure 8; Table 1); 
Table 1. The mean directions and paleomagnetic poles of the study objects

\begin{tabular}{|c|c|c|c|c|c|c|c|c|c|c|c|}
\hline \multirow{2}{*}{ no. } & \multirow{2}{*}{ Comp. } & \multirow[t]{2}{*}{$\mathrm{N}$} & \multirow[t]{2}{*}{$\mathrm{D}$} & \multirow[t]{2}{*}{ I } & \multirow[t]{2}{*}{$\mathrm{k}$} & \multirow[t]{2}{*}{$\alpha_{95}$} & \multicolumn{2}{|r|}{ Fold test } & \multirow[t]{2}{*}{$\Phi$} & \multirow[t]{2}{*}{$\Lambda$} & \multirow[t]{2}{*}{$d p / d m$} \\
\hline & & & & & & & $\mathrm{DC}$ & $\mathrm{CFT}$ & & & \\
\hline
\end{tabular}

South-western Pribaykalye

site 12 (Kurtun formation) $\varphi=52.7 ; \lambda=105.8$

\begin{tabular}{|c|c|c|c|c|c|c|c|c|c|c|c|c|c|}
\hline & \multirow{2}{*}{ A } & \multirow[t]{2}{*}{28} & $\mathrm{~s}$ & 92.7 & 44.8 & 29.6 & 5.1 & \multirow[t]{2}{*}{-} & \multirow{2}{*}{-} & \multirow[t]{2}{*}{-} & \multirow[b]{2}{*}{-74.0} & \multirow[b]{2}{*}{132.4} & \multirow[b]{2}{*}{$3.4 / 4.7$} \\
\hline 1 & & & $\mathrm{~g}$ & 351.0 & 57.4 & 74.3 & 3.2 & & & & & & \\
\hline \multirow[t]{2}{*}{$2^{*}$} & \multirow{2}{*}{ B1 } & \multirow[t]{2}{*}{21} & $\mathrm{~s}$ & 352.5 & 42.7 & 13.2 & 5.1 & \multirow{2}{*}{+} & \multirow{2}{*}{+} & \multirow{2}{*}{$?$} & \multirow[t]{2}{*}{-61.5} & \multirow[t]{2}{*}{120.2} & \multirow[t]{2}{*}{$3.9 / 6.3$} \\
\hline & & & $\mathrm{g}$ & 336.7 & 2.4 & 7.3 & 7.0 & & & & & & \\
\hline \multirow[t]{2}{*}{3} & \multirow[t]{2}{*}{$\mathrm{B} 2$} & \multirow[t]{2}{*}{15} & $\mathrm{~s}$ & 224.9 & 0.2 & 6.0 & 17.0 & \multirow{2}{*}{$?$} & \multirow[t]{2}{*}{$?$} & \multirow[t]{2}{*}{$?$} & \multirow[t]{2}{*}{-25.3} & \multirow[t]{2}{*}{54.5} & \multirow[t]{2}{*}{$8.5 / 17.0$} \\
\hline & & & $\mathrm{g}$ & 220.2 & -5.3 & 6.6 & 16.1 & & & & & & \\
\hline
\end{tabular}

site 10 (Ushakovka formation) $\varphi=52.7 ; \lambda=105.8$

\begin{tabular}{|c|c|c|c|c|c|c|c|c|c|c|c|c|c|}
\hline \multirow[t]{2}{*}{4} & \multirow{2}{*}{ B1 } & 29 & $\mathrm{~s}$ & 347.2 & 37.7 & 30.0 & 5.0 & \multirow{2}{*}{+} & \multirow{2}{*}{ \pm} & \multirow{2}{*}{+} & \multirow{2}{*}{-56.9} & \multirow[t]{2}{*}{128.1} & \multirow[t]{2}{*}{$3.5 / 5.9$} \\
\hline & & & $\mathrm{g}$ & 36.6 & 79.1 & 12.7 & 7.8 & & & & & & \\
\hline \multirow[t]{2}{*}{5} & \multirow{2}{*}{ B2 } & 16 & $\mathrm{~s}$ & 218.0 & -8.4 & 7.1 & 14.8 & \multirow{2}{*}{$?$} & \multirow{2}{*}{$?$} & \multirow[t]{2}{*}{$?$} & \multirow[t]{2}{*}{-32.3} & \multirow[t]{2}{*}{59.2} & \multirow[t]{2}{*}{$7.5 / 14.9$} \\
\hline & & & $\mathrm{g}$ & 248.9 & -27.9 & 6.6 & 15.5 & & & & & & \\
\hline
\end{tabular}

Eastern Prisayanye

site 16-18 (transit zone of Motyi-Irkut formations) $\varphi=52.1 ; \lambda=103.7$

\begin{tabular}{|c|c|c|c|c|c|c|c|c|c|c|c|c|c|}
\hline \multirow{2}{*}{6} & \multirow{2}{*}{$\mathrm{A}$} & \multirow[t]{2}{*}{40} & $\mathrm{~s}$ & 341.8 & 56.7 & 90.2 & 2.4 & \multirow[t]{2}{*}{$?$} & \multirow[t]{2}{*}{+} & \multirow[t]{2}{*}{+} & \multirow[t]{2}{*}{-70.4} & \multirow[t]{2}{*}{151.6} & \multirow[t]{2}{*}{$2.5 / 3.5$} \\
\hline & & & g & 337.9 & 58.4 & 82.4 & 2.5 & & & & & & \\
\hline \multirow[t]{2}{*}{7} & \multirow{2}{*}{ B1 } & \multirow[t]{2}{*}{22} & $\mathrm{~s}$ & 356.7 & 40.3 & 20.2 & 6.8 & \multirow{2}{*}{+} & \multirow[t]{2}{*}{$?$} & \multirow{2}{*}{+} & \multirow[t]{2}{*}{-60.8} & \multirow[t]{2}{*}{109.9} & \multirow[t]{2}{*}{$5.0 / 8.2$} \\
\hline & & & $\mathrm{g}$ & 356.0 & 42.2 & 20.1 & 6.8 & & & & & & \\
\hline \multirow[t]{2}{*}{$8^{* *}$} & \multirow{2}{*}{ B2 } & & $\mathrm{s}$ & 207.3 & 2.3 & 13.3 & 13.8 & & & & \multirow[t]{2}{*}{-32.0} & \multirow[t]{2}{*}{71.0} & \multirow[t]{2}{*}{$6.9 / 13.8$} \\
\hline & & & $\mathrm{g}$ & 206.8 & -3.5 & 10.7 & 15.5 & & & & & & \\
\hline
\end{tabular}

site 17 (Irkut formation) $\varphi=52.1 ; \lambda=104.1$

\begin{tabular}{|c|c|c|c|c|c|c|c|c|c|c|c|c|c|}
\hline \multirow[t]{2}{*}{9} & \multirow[t]{2}{*}{ B1 } & 12 & $\mathrm{~S}$ & 359.9 & 43.0 & 22.6 & 9.3 & \multirow[t]{2}{*}{+} & \multirow[t]{2}{*}{+} & \multirow[t]{2}{*}{+} & \multirow[t]{2}{*}{-62.9} & \multirow[t]{2}{*}{104.3} & \multirow[t]{2}{*}{$7.1 / 11.5$} \\
\hline & & & g & 356.0 & 60.6 & 9.5 & 14.9 & & & & & & \\
\hline 10 & B2 & 11 & $\mathrm{~s}$ & 25.8 & 5.3 & 102.1 & 4.5 & + & + & $?$ & -36.1 & 71.6 & $2.3 / 4.5$ \\
\hline & & & $\mathrm{g}$ & 28.2 & 30.1 & 62.3 & 5.8 & & & & & & \\
\hline
\end{tabular}

Mean directions of B1 and B2 components (all sites) for $\varphi=52.7 ; \lambda=105.8$

\begin{tabular}{|c|c|c|c|c|c|c|c|c|c|c|c|c|}
\hline \multirow{2}{*}{ B1 } & 4 & $\mathrm{~s}$ & 354.4 & 41.4 & 238.2 & 6.0 & \multirow{2}{*}{+} & \multirow{2}{*}{+} & \multirow[t]{2}{*}{$?$} & \multirow{2}{*}{-60.8} & \multirow[t]{2}{*}{116.3} & \multirow[t]{2}{*}{$4.5 / 7.3$} \\
\hline & & $\mathrm{g}$ & 351.3 & 48.2 & 5.6 & 42.8 & & & & & & \\
\hline \multirow{2}{*}{ B2 } & 4 & $\mathrm{~s}$ & 214.8 & -3.9 & 73.6 & 10.8 & \multirow{2}{*}{+} & \multirow{2}{*}{+} & \multirow{2}{*}{$?$} & \multirow[t]{2}{*}{-31.6} & \multirow[t]{2}{*}{63.7} & \multirow[t]{2}{*}{$5.4 / 10.8$} \\
\hline & & $\mathrm{g}$ & 221.2 & -18.3 & 13.2 & 26.3 & & & & & & \\
\hline
\end{tabular}

Note: Comp. - denotes the magnetization components; no. - the number of the samples; D - the declination; I - the inclination; $\mathrm{k}$ - precision parameter; $\alpha_{95}$ - the radius of the confidence circle; $\Phi$ and $\Lambda$ - denote the latitude and longitude of the paleomagnetic pole; $d p / d m$ are the semiaxes of the pole confidence oval; $\varphi$ and $\lambda$ are the geographical latitude and longitude of the study object; $\mathrm{s}$ and $\mathrm{g}$ denote the stratigraphic and geographic systems of the coordinates, respectively. The fold tests: DC (direction-correction fold test [Enkin, 1990]; NFT (new fold test) [Shipunov, 1995]; CFT (correlation fold test [Bazhenov and Shipunov, 1991]. * The average direction calculated for 21 "end points" and 42 remagnetization circles. ${ }^{* *}$ The direction reported by [Kravchinsky et al., 2001].

[31] (3) 15 samples were found to contain the intermediate B2 component of the SW declination and shallow inclination, identified in the temperature range of $220-280^{\circ} \mathrm{C}$ (see $\mathrm{g}$ and $\mathrm{h}$ in Figure 6; Figure 8; Table 1). One sample showed this component in the temperature range of $310-460^{\circ} \mathrm{C}$; it seems to be the final one, goinf to origin of the diagram of Zijderveld. We failed to date the B2 component relative to the folding event, like in the case of the Kurtun Formation. 


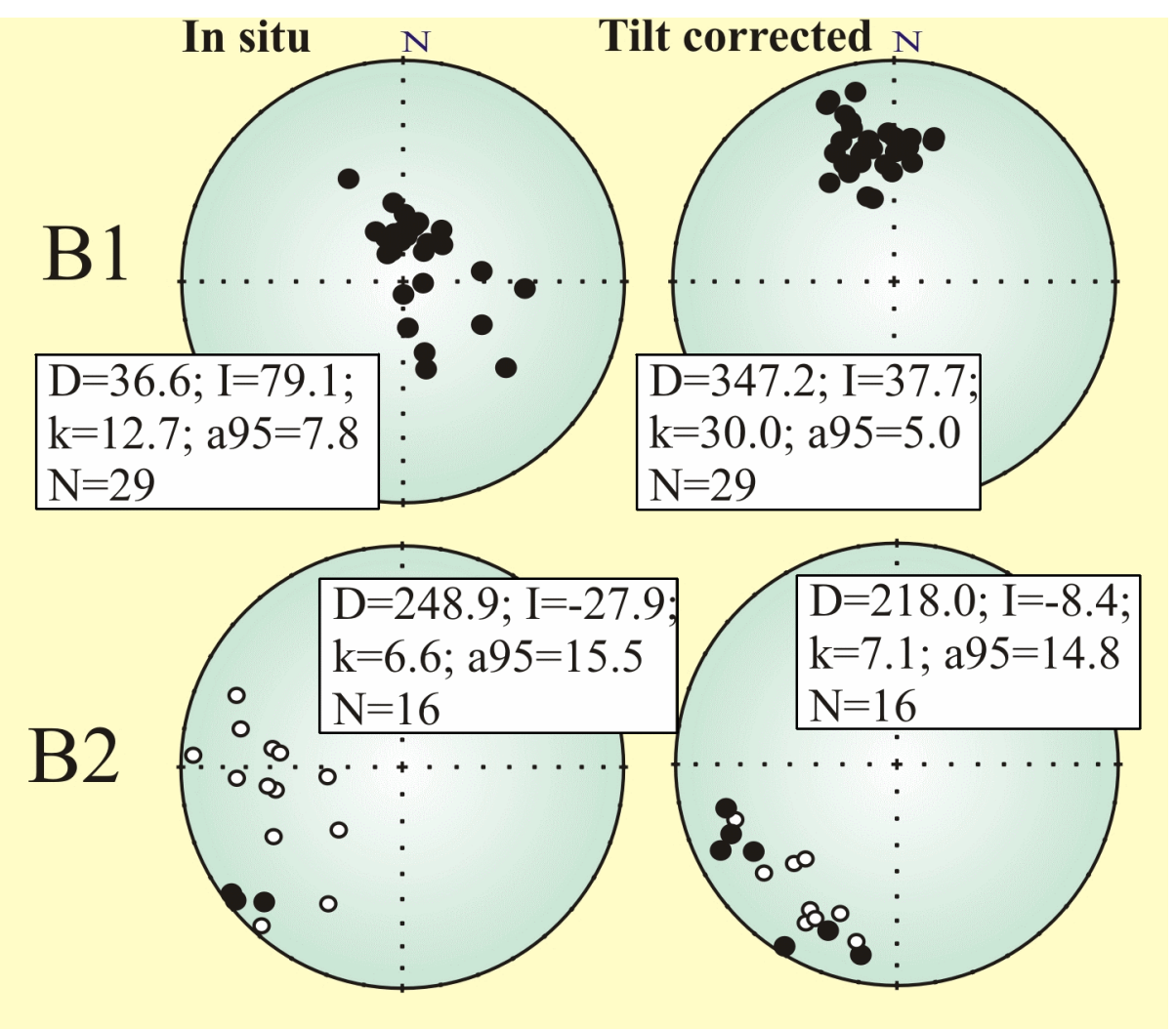

Figure 8. The distribution of the vectors of the B1 and B2 components of the Ushakovka Formation in the southwest Baikal region (Kurtun River area). The solid circles denote projections on the lower hemisphere, the open ones, on the upper.

\section{East Sayan Region}

[32] Transition from the Moty to the Irkut formation, Sites 16 and 18. The NRM values of the red sandstone and siltstone vary from $3 \mathrm{~mA} \mathrm{~m}^{-1}$ to $13 \mathrm{~mA} \mathrm{~m}^{-1}$, the average value being $5 \mathrm{~mA} \mathrm{~m}^{-1}$, the magnetic susceptibility values ranging from 80 to $170 \times 10^{-6}$ with an average value of $120 \times 10^{-6}$ SI units. The $I_{\mathrm{rs}}(T)$ curves (Figure $5 \mathrm{~d}$ ) indicate the presence of one magnetic mineral, hematite. The heating of up to $200^{\circ} \mathrm{C}$ removes $50 \%$ of the magnetization. The further heating causes a gentle NRM decay almost to zero at the temperature close to $T_{\mathrm{c}}$ of hematite. At the temperature of $550^{\circ} \mathrm{C}$ the magnetic susceptibility value begins to grow, its growth amounting averagely to $40 \%$ during the last heating $\left(680^{\circ} \mathrm{C}\right)$.

[33] The $I_{\mathrm{rs}}$ value did not grow essentially, although the $I_{\mathrm{rs}}(T)$ curves of the second heating showed sometimes the newly formed magnetite. The "material" for its formation seems to be the iron oxide present in the sandstone cement, and also hydromica [Psarchik, 1963].

[34] The identical magnetic properties and component composition of the rocks at Sites 16 and 18, as well as the same stratigraphic level, the insignificant variations in the dip and strike, and the geographical vicinity of the outcrops allow one to consider these rocks as one object.
[35] The magnetic cleaning showed three components of magnetization:

[36] (1) the low-temperature component which breaks down during the heating of more than $200^{\circ} \mathrm{C}$. This component is close to the direction of the modern magnetic field (not discussed here);

[37] (2) the medium- to high-temperature A component, identified in the temperature range of $150-200^{\circ} \mathrm{C}$ and higher either as a intermediate one (not extending to the coordinate origin of the Zijderveld diagram), or (locally) as the only component identified in the sample, destroyed at the Curie temperature of hematite (Figures 9a and 10);

[38] (3) the high-temperature B1 component of the same polarity (Figure 9a, b, and c, and Figure 10), which usually follows the "intermediate" A component and decays at $680^{\circ} \mathrm{C}$. The A and B1 components are formally pre-folding ones (Table 1).

[39] For Site 16, using the rocks older than those investigated in our present study, Kravchinsky et al. [2001] obtained the bipolar directions of shallow inclinations, corresponding (in our terminology) to the B2 component (Table 1). We obtained the B2 direction only in one sample collected at Site 18 (Figure 9d) in the upper part of the studied outcrop.

[40] Irkut Formation, Site 17. The NRM values vary from $2.0 \mathrm{~mA} \mathrm{~m}^{-1}$ to $10.1 \mathrm{~mA} \mathrm{~m}^{-1}$, averaging $5 \mathrm{~mA} \mathrm{~m}^{-1}$; the magnetic susceptibility value varies from 110 


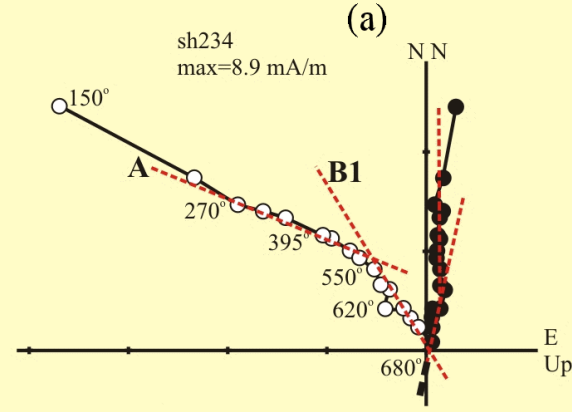

(c)

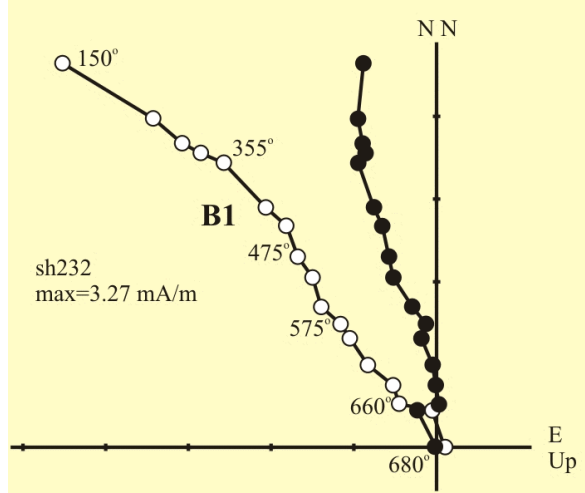

(e)

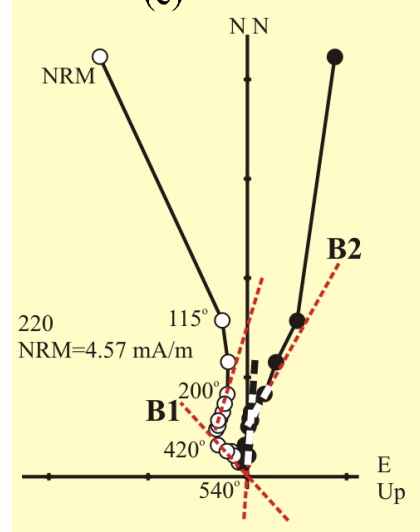

(d)

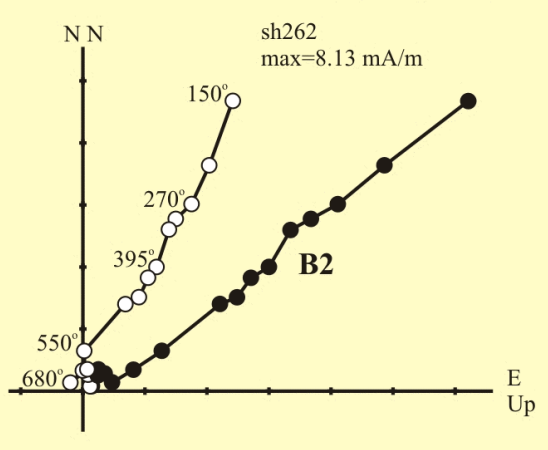

(f)

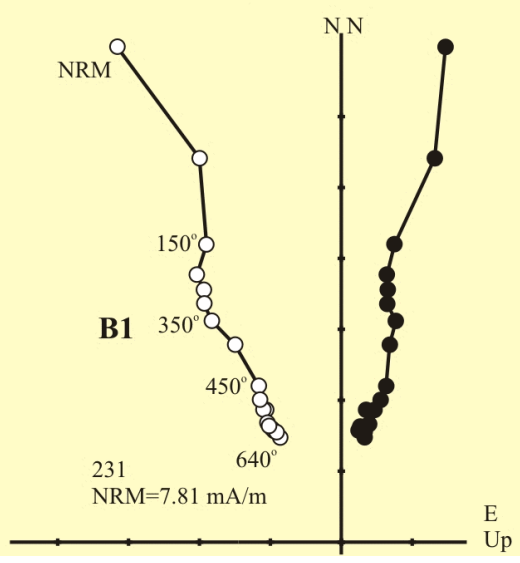

\section{p}

(b)

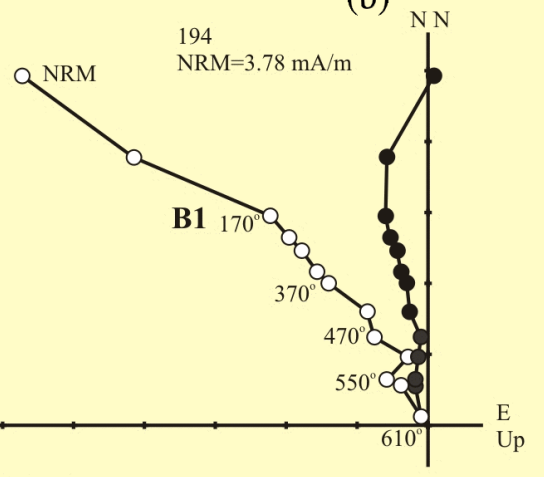

$(\mathrm{g})$

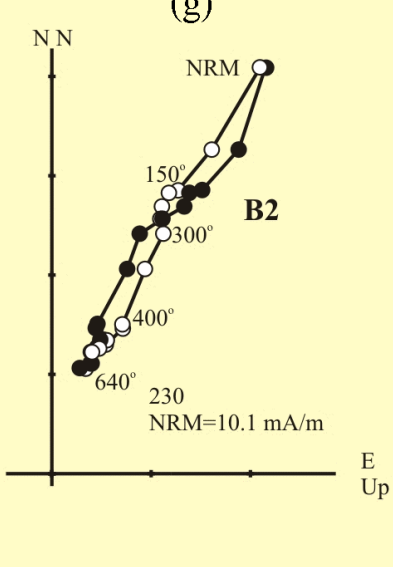

Figure 9. The typical Zijderveld diagrams for the rocks of the East Sayan area. The a-d - diagrams show the transition from the Moty to the Irkut formations, $\mathrm{e}-\mathrm{g}-$ presenting the Irkut Formation. The solid circles denote the projections of the magnetization vector onto the horizontal plane, the open ones, onto the vertical plane. All diagrams are presented in the stratigraphic system of the coordinates.

to $260 \times 10^{-6}$ SI units, averaging $180 \times 10^{-6}$ SI units. The magnetization carrier is hematite, the $I_{\mathrm{rs}}(T)$ curves of second heating generally repeating the initial $I_{\mathrm{rs}}(T)$ curves (see e in Figure 5). The characteristic feature is the magnetic susceptibility decay at the end of the heating, amounting to $50 \%$ at the last cleaning steps. The viscous remanent magnetization is higher than $50 \%$ NRM, being removed by heating up to $100^{\circ} \mathrm{C}$.

[41] Two magnetization components were clearly resolved in all 15 samples that were studied: 1) the intermediate B2 high-temperature component isolated in the temperature interval of $115^{\circ} \mathrm{C}$ to $200-300^{\circ} \mathrm{C}$ (Figure 9e). In one sample this component is final one ( $\mathrm{g}$ in Figure 9) and 2) high- temperature B1 component revealing from $250-475^{\circ} \mathrm{C}$ and destroying completely at $T_{\mathrm{c}}$ of hematite (Figure $9 \mathrm{e}$ and $\mathrm{f}$ ). Another sample showed the B1 component of reversed polarity. Both components had a pre-folding age (Figure 11, Table 1).

\section{Comparison of the Average Directions}

[42] As follows from the above data, the Vendian rocks of the Baikal and Sayan regions, differing both in their lithologies and magnetic characteristics, show three magnetization 


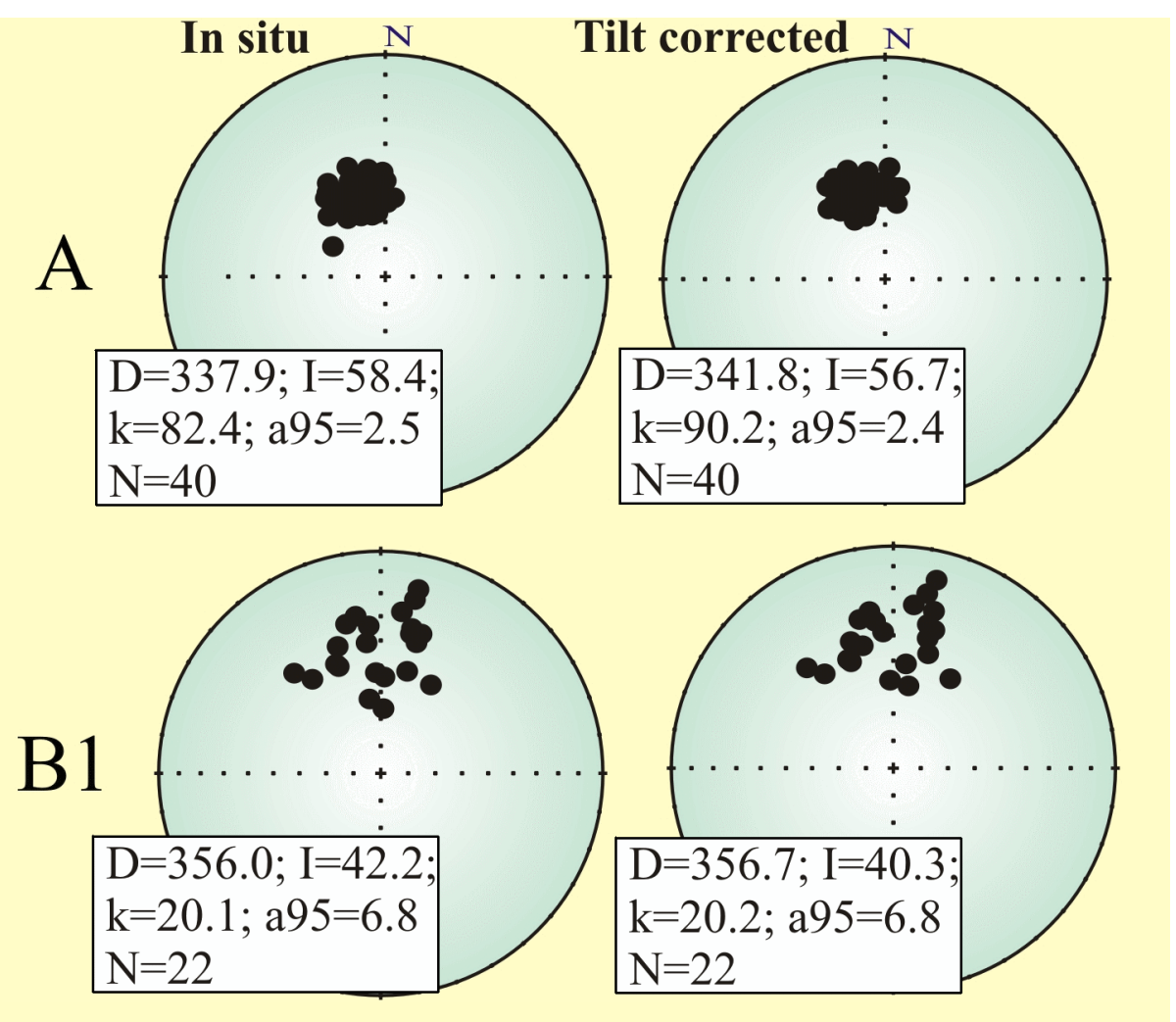

Figure 10. The distribution of the B1 and B2 component vectors in the Moty-Irkut Fms transitory zone in the East Sayan area (Irkut River). The solid circles denote the projection onto the lower hemisphere, the empty ones, onto the upper.

components of different nature, which are preserved in the objects of our study in different combinations (Figure 12, Table 1).

[43] A component. The metachronic component has been recorded in the rocks of the Kurtun Formation in the Baikal region, where its post-folding age has been proved, and also in the transition parts of the Moty and Irkut formations in the Sayan area. Some insignificant differences in the dips and strikes between Sites 16 and 18 (Sayan area) preclude the exact dating of the A component relative to the time of the Sayan deformations, however the average directions of this component in Sites 16 and 18 are notably closer in the stratigraphic system of the coordinates, as compared to the geographical one. The single polarity A component is characterized by NNW declinations and inclinations of about $60^{\circ}$.

[44] Our analysis of the paleomagnetic data available for the Siberian platform shows that the pole of the A component differs significantly from all post-Early Cambrian paleomagnetic poles, this suggesting its Early Cambrian or Precambrian age (Figure 13). In this case, however, the post-folding age of this component suggests that the folding in the studied areas of the Southwestern Baikal region has the Late Vendian age, which has not been confirmed in terms of structural geology yet.
[45] The B1 component has been isolated in all areas of study, has a pre-folding age, both in site volumes and in the comparison of the sites average directions and is predominantly a monopolar one. This component has northern declinations and inclinations of about $40^{\circ}$.

[46] The B2 component is a bipolar component characterized by low inclinations and NE-SW declinations. It is usually distinguished in Zijderveld diagrams either as an intermediate or as a final component. The pre-folding age of the B2 component was proved only in one outcrop, using a small number of samples where it is intermediate relative to the B1 component (Site 17). The comparison of the data obtained for the B2 component at the regional level suggests the prefolding time of its formation.

[47] None of the directions corresponds to any of the known post-Vendian paleomagnetic poles of Siberia (Figure 13). At the same time the directions, close to the B1 component, were obtained for the Vendian Ust-Tagul and Moty Formations (Tagul and Toysuk rivers) [Gurevich, 1981; Shatsillo et al., 2001].

[48] From the other hand the bipolar components, close to the B2 direction, are known for some Vendian formations of North Baikal and Patom Upland regions (Minia Formation and Nokhtuisk Formation) [Konstantinov, 1998]. Besides, as it has been mentioned above, B2 direction has been isolated in the rocks of the Moty Formation exposed in 


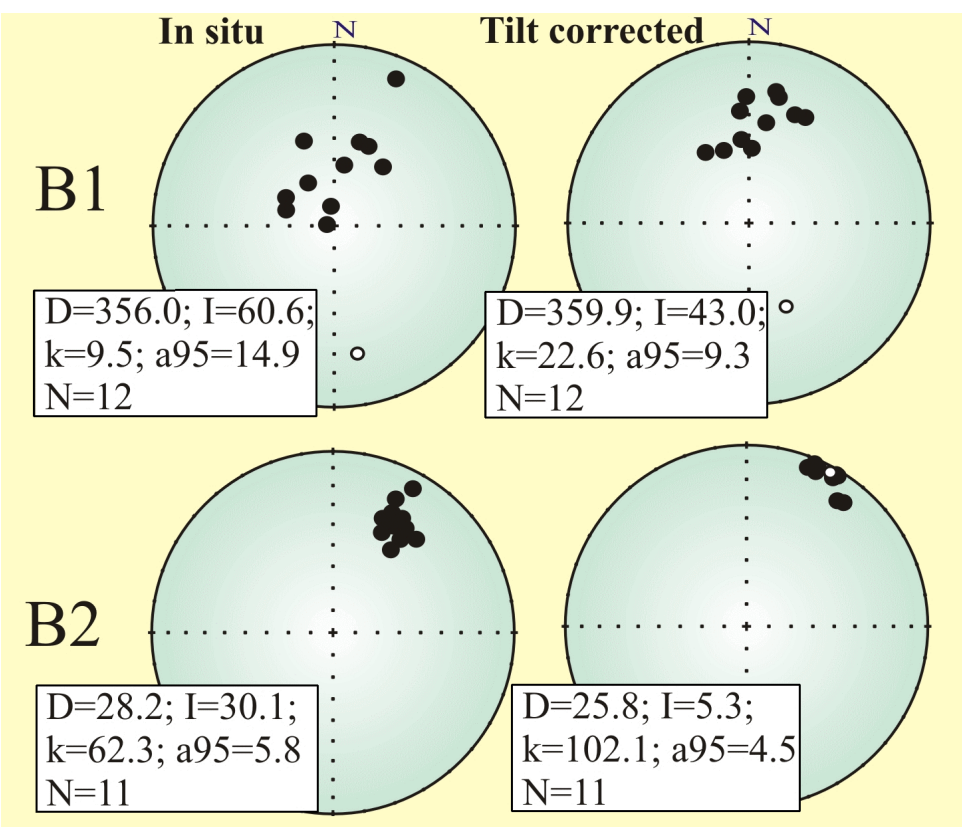

Figure 11. The distribution of the B1 and B2 components of the Irkut Formation in the East Sayan area (Olkha River). The solid circles denote the projection onto the lower hemisphere, the open ones, onto the upper one.

the Irkut River valley (Shaman Mountain)in the Sayan area [Kravchinsky et al., 2001].

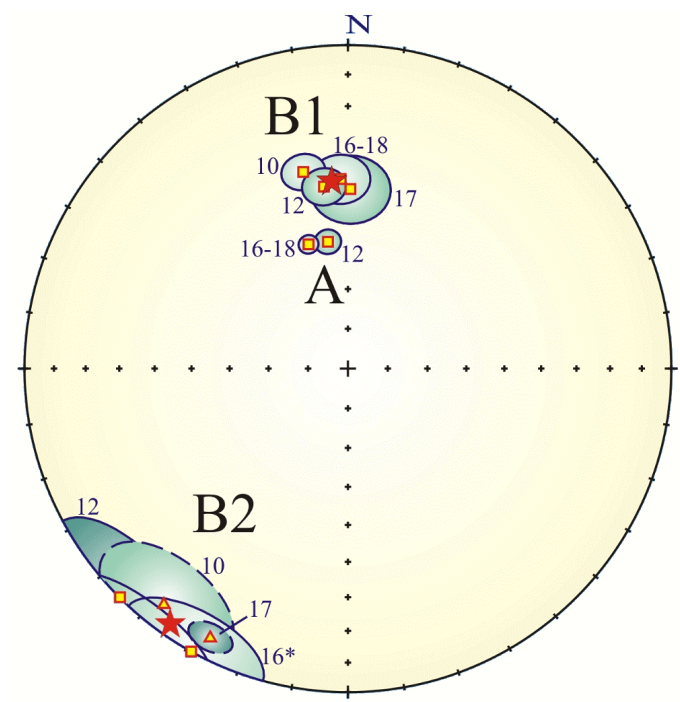

Figure 12. The average directions of the A, B1, and B2 components for all objects of study. The squares show the projections of the vectors onto the lower hemisphere, the triangles, onto the upper one. Site 12 for the A component is given in the geographic system of the coordinates, the others, in the stratigraphic one. Site $16^{*}$ is given after Kravchinsky et al. [2001].

\section{Discussion of the Results}

[49] Thus, besides the metachronous A component (not discussed here), two substantially different paleomagnetic directions, B1 and B2, were found in the rocks investigated in the SW Baikal and East Sayan areas. Below follow their main characteristics.

[50] 1. The magnetization components corresponding to these directions exist objectively and are not any artifacts associated with the data processing.

[51] 2. Both components are often found in the sections, spaced dozens and hundreds of kilometers apart, representing different areas of the Siberian Platform with different geologic histories.

[52] 3. The B1 direction is usually more distinct, characterized by moderate positive inclinations and northern declinations, is usually a monopolar one and is interpreted as a prefolding one, both at the sites level and regional levels.

[53] 4. The B2 direction is a bipolar one and is characterized by low inclinations and NE-SW declinations. The fold tests performed in site volumes usually give unconclusive results, this being obviously caused by a "noisy" paleomagnetic signal. Yet, the fold test at the regional level indicates the obvious pre-folding age of this direction.

[54] 5. No association of these directions with any definite rock type has been found. Both of them are carried by hematite as well as by magnetite.

[55] 6. The B2 direction has been distinguished either as a final ("end-points") one or as an intermediate component relative to the B1 direction, none of the samples showing inverse relationships.

[56] 7. The B1 and B2 directions were found in all objects studied, which precludes the explanation of their existence by the effect of local tectonics. 


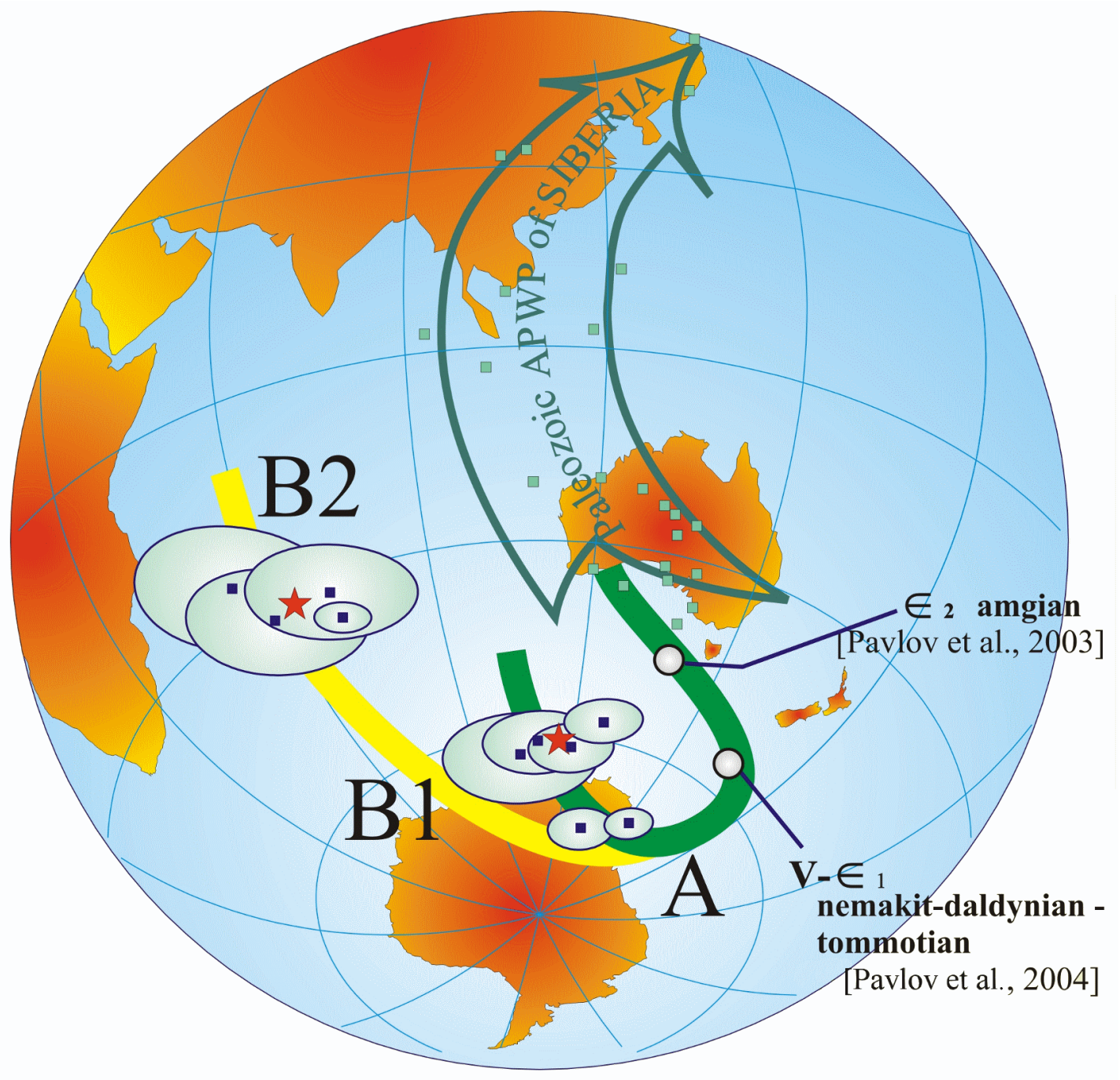

Figure 13. The paleomagnetic poles for the A, B1, and B2 components.

[57] 8. In continuous monofacies rock sequences these directions often replace each other, producing their complex combinations.

[58] 9. Both directions yield paleomagnetic poles which differ significantly from the known Phanerozoic poles of Siberia, that, in some degree, suggests the Precambrian age of their formation.

[59] 10. The angle between the B1 and B2 directions is about $45^{\circ}$.

[60] No objective arguments have been obtained so far in favor of the priority of one of these directions, or in favor of the fact that either of them has been produced by the remagnetization of rocks. The paleomagnetic pole, corresponding to the B1 component, is relatively close to the Middle and Late Cambrian poles of the Siberian Platform (Figure 13), this allowing one to infer the Middle-Late Cambrian age of the B1 component. However, in spite of its relative proximity, the pole corresponding to this component differs significantly from the Middle-Late Cambrian poles [Gallet et al., 2003; Pavlov and Gallet, 1998], this precluding the for- mation of the B1 component as a result of the Middle-Late Cambrian remagnetization.

[61] It is somewhat more difficult to correlate the B1 component with the Early Cambrian pole of the platform (Figure 13), because the position of the latter is a subject of hot discussion, for example, see [Pisarevsky et al., 1997; Smethurst et al., 1998a]. However, even in this case the pole of the B1 component resides at some distance from the Early Cambrian poles proposed earlier [Kirschvink and Rozanov, 1984; Pavlov et al., 2004; Pisarevsky et al.,, 1997], this providing a basis for the early formation of the B1 component.

[62] Therefore, we have to admit that the observed directions seem to have originated during or soon after the accumulation of the rocks, that is, during the Nemakit-Daldynian time. However, the simultaneous occurrence in rocks of two discordant directions, almost of the same age, contradicts the hypothesis of a geocentric axial dipole, characterizing the "geometry" of the time-averaged magnetic field of the Earth. 
[63] The data reported in this paper may indicate some unusual (different from the modern ) behavior and structure of the magnetic field of the Earth at the end of Vendian time. It's obvious that if the presence of two competing directions of the same age is the consequence of the anomalous behavior of the magnetic field, this phenomenon must have a planetary scale and be observed in other continents.

[64] Our analysis of the World Paleomagnetic Database (GPMDB2002 http://dragon.ngu.no [Pisarevsky and McElhinny, 2003b] revealed that the presence of two discordant paleomagnetic directions is characteristic of not only the rocks of the Siberian platform. Similar objects have been observed for the Late Precambrian-Early Cambrian rocks of North America, West Europe, Mongolia, and Altai (Table 2).

[65] Below follow the criteria used in this study to locate the objects in question:

[66] 1. We analyzed all paleomagnetic determinations that covered the time interval of 650-518 Ma.

[67] 2. Then we selected the paired determinations obtained for the same geological structures with strictly coinciding geographic coordinates of sampling sites for each pair of poles. This choice allowed us to avoid the potential effect of tectonic movements in the respective areas, the ignorance of which would have resulted in errors during the comparison of the paleomagnetic directions.

[68] 3. The aim of the next step was to identify and select paired paleomagnetic determinations obtained strictly for the rocks of the same age (as it is indicated in World Paleomagnetic Database).

[69] After this kind of selection we calculated the angular distances "gamma" (Table 2) between the paired paleomagnetic poles for each object.

[70] As a result of our selection, we discovered 17 objects for which 2 to 4 paleomagnetic determinations are available, the "gamma" values of which embrace almost the whole spectrum of the potential values $\left(5^{\circ}\right.$ to $\left.88^{\circ}\right)$, the average value being about $45^{\circ}$ (see Table 2 ). The most frequently observed gamma values belong to the $44-55^{\circ}$ interval, which is illustrated by the presence of a plateau in the diagram (Figure 14). A similar plateau was found in the interval of 5$10^{\circ}$ and reflects the presence of pairs with closely similar paleomagnetic directions, which looks to be fairly natural. The intervals with the "gamma" values higher than $10^{\circ}$ and lower than $44^{\circ}$, as well as those higher than $55^{\circ}$, can be interpreted as a mixture of competing components in different proportions and (or) as the presence, in addition to ancient "primary" magnetization components, of some younger remagnetization ones (Figure 15). Thus, it can be concluded that the value of $44-55^{\circ}$ between the discordant paired VendianEarly Cambrian poles is a characteristic, most frequently observed value. The average "gamma" value for the plateau is about $50^{\circ}$.

[71] To sum up, 9 pairs of paleomagnetic poles with an angular distance "gamma", similar to that of the Siberian objects, were determined for the time interval discussed (Table 2). These data were obtained for the objects that had been formed in different geodynamic environments, in different continents, and are composed of different sedimentary, volcanic, or intrusive rocks.

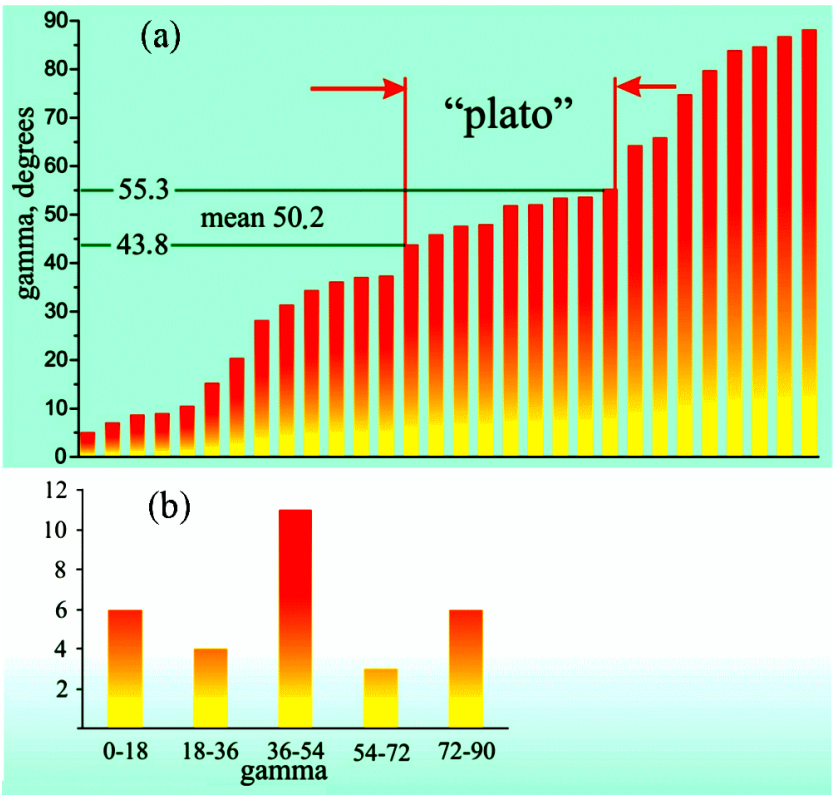

Figure 14. (a) The diagram of "gamma" values for the paired poles of the world (analysis of the Paleomagnetic Database). Corresponding to each column is the angle between the two directions; (b) is a histogram of the "characteristic" gamma values of the world. The horizontal axis shows the "gamma" values with step of $18^{\circ}$, the vertical axis showing the number of the paired poles.

[72] It should also be mentioned that some weakening of requirements of above point 3 (the ages overlapped but did not show any exact coincidence) allowed us to locate 1.5-2 times more paired poles with an expected angular distance between them. That is, even a fairly simple testing procedure, based on the formal data selection criteria, proves that the presence of two discordant directions in the VendianEarly Cambrian is a planetary feature, apparently reflecting the anomalous behavior of the Earth's magnetic field in this time.

[73] In addition to the above, new paleomagnetic data that have been obtained recently for transitory Upper VendianLower Cambrian beds of "Chekurovka" section (norteastern Siberian Platform, [Pavlov et al., 2004]) should be mentioned. In this section the "primary" mono- and bipolar discordant directions, different from the Phanerozoic ones, also have been found. The angle distance between the paleomagnetic poles corresponding to these directions is $58^{\circ}$.

[74] To sum up, we have two paleomagnetic directions, one of which (B1) corresponds to the paleomagnetic pole which continues gradually the Siberian Phanerozoic Apparent Polar Wander, the other (B2) producing a pole located at a significant distance from the known Phanerozoic poles of close age (Figure 13). The comparison of the poles corresponding to the B1 and B2 components with the Amga pole of the Siberian Platform [Pavlov et al., 2003] showed the respective angular distances between the poles to be $23^{\circ}$ and $57^{\circ}$. Thus, proceeding from the principle of movement minimization, we can rank the B1 and B2 components as responding 


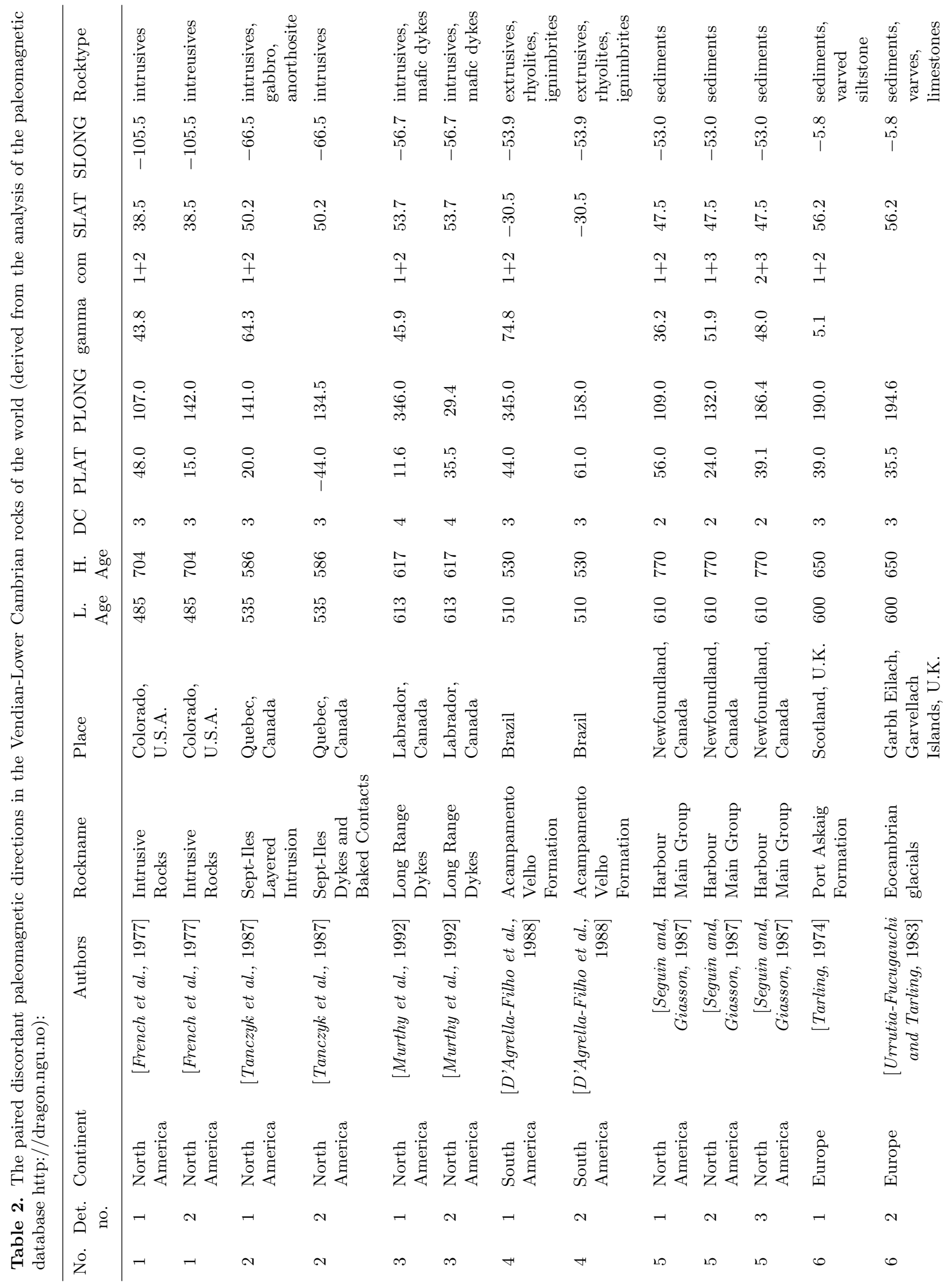




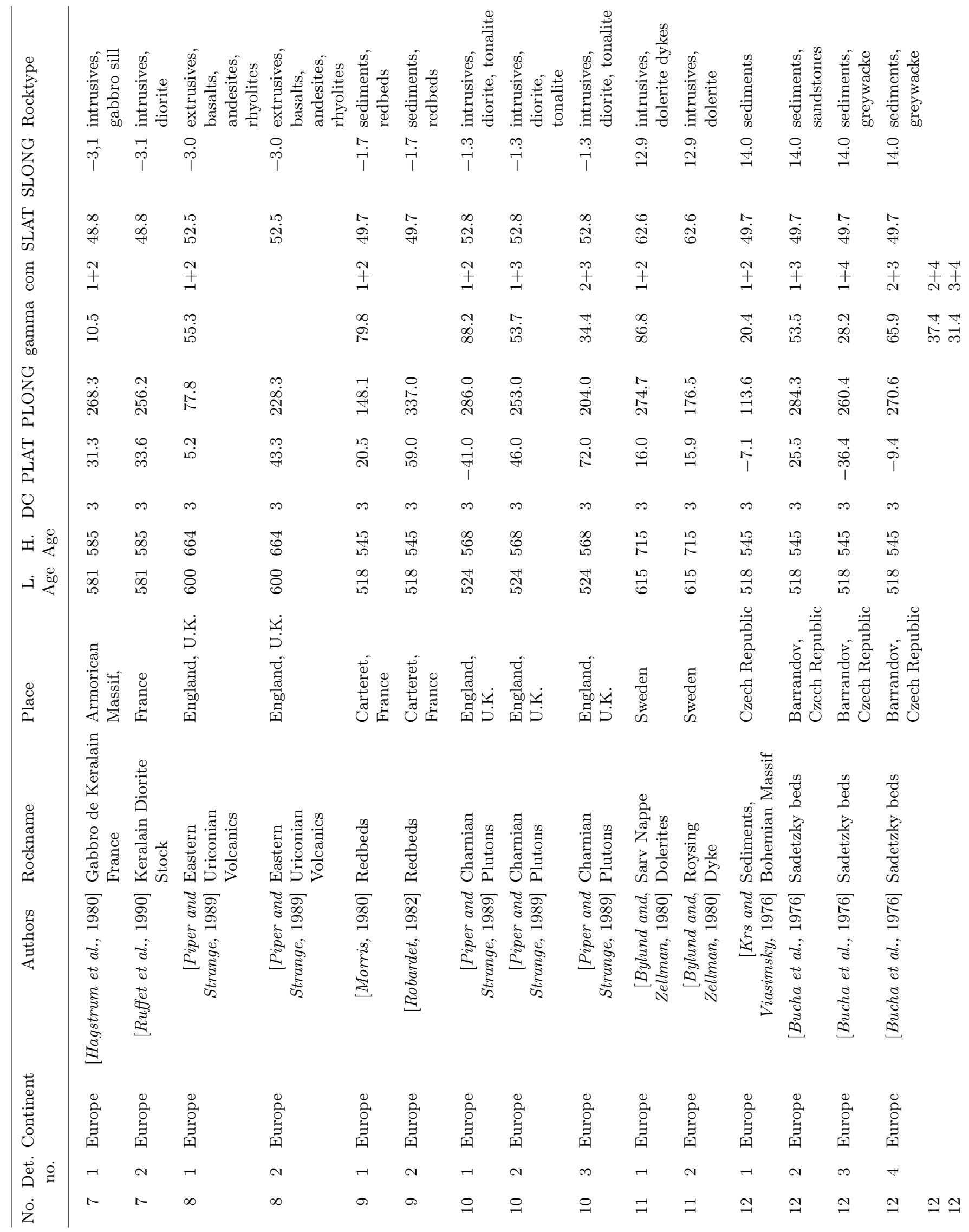




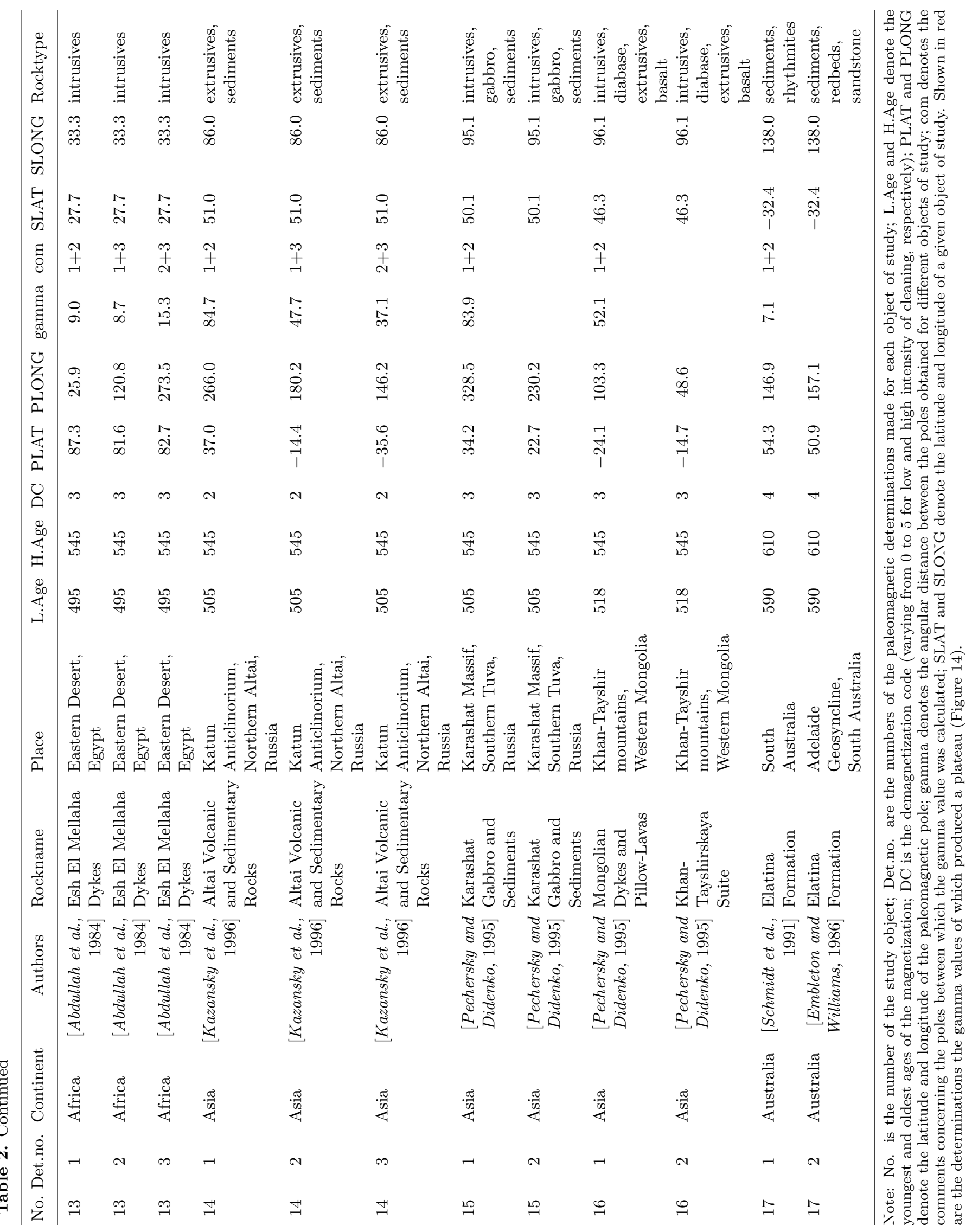


to a normal and an anomalous directions correspondingly.

[75] Proceeding from the above considerations, following the authors of paper [Pavlov et al, 2004] we suggest, as one of possible variants, the following model which allows one to describe the "geometry" of the Earth magnetic field for the Vendian-Early Cambrian time.

[76] The observed behavior of the geomagnetic field can be explained by the existences of two modes of its generation, periodically replacing one another (Figure 16): the normal, mostly monopolar mode, recorded in the B1 paleomagnetic direction, when the magnetic dipole aligned with the axis of the Earth rotation, and the anomalous mode, marked by the B2 direction, which was characterized by frequent polarity changes and by the deviation of the geomagnetic dipole by angle of about $50^{\circ}$ from the rotation axis.

\section{Testing of the Model}

[77] As follows from the above evidence, the world paleomagnetic data do not contradict the model the geomagnetic field behavior proposed here. However, a question arises concerning the reliability of these data. Some of them were obtained using some "old" techniques and have a low reliability index (Table 2). Moreover, most of the data were obtained for fold (Hercynean and Caledonian) belts, where remagnetization is rather probable. At the same time, such the universal tool for dating of magnetization components as apparent polar wander paths (APWP) of ancient platforms is, can be very rarely used in fold areas. Hence, the most reliable way to test the model suggested here is the analysis of the Vendian paleomagnetic data obtained for the ancient platforms, where the APWP's are most substantiated.

[78] Laurentia. At the present time two contradicting views are discussed for the Vendian pole of Laurentia (Figure 17, Table 3), this matter being the subject of hot discussion [Meert and Van der Voo, 2001; Pisarevsky et al., 2000, 2001].

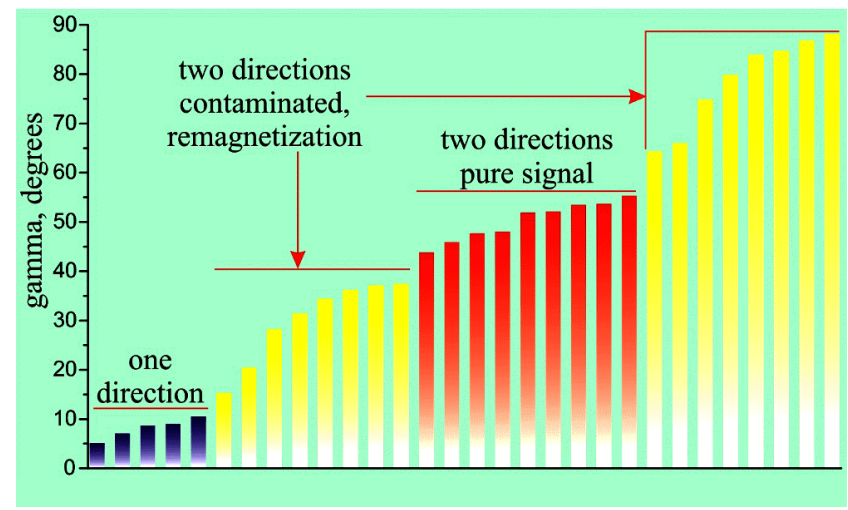

Figure 15. The diagram of "gamma" values for the paired poles of the world (based of the analysis of the paleomagnetic database). See the text for explanations.

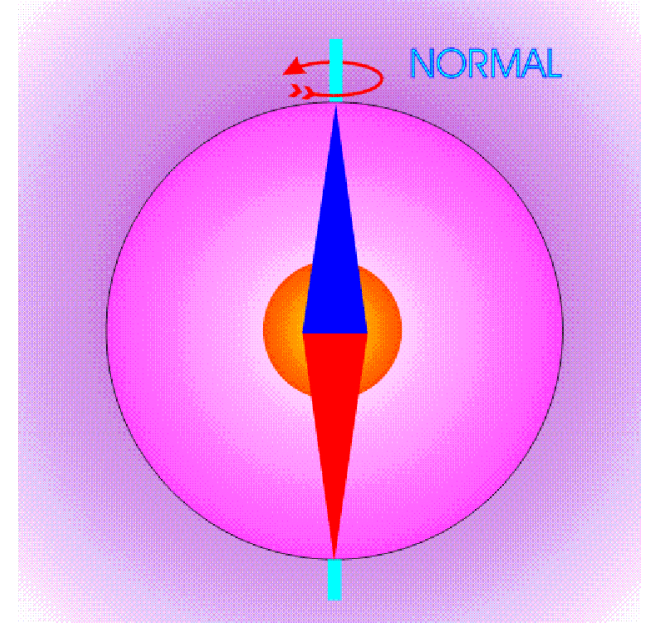

Figure 16. Model, describing the geomagnetic field behavior in Late Vendian-Lower Cambrian.

[79] The supporters of "version-2" [Meert and Van der Voo, 2001] believe that the poles of Group 1 were produced as the result of the rock remagnetization in Late Cambrian time (because of the vicinity of these poles to the basement of the Phanerozoic APWP of Laurentia).

[80] In particular, the pole Catoctin-B (Group 1), corresponding to prefolding and bipolar direction of the Catoctin volcanic rocks, was interpreted as a metachronous (Late Cambrian) one, because, in contrast to the Catoctin A pole (Group 2), no baked contact test was made proceeding from the specific geological situation [Meert and Van der Voo, 2001; Meert et al., 1994] (Table 3, Figure 17). One cannot agree with this view for the following reasons:

[81] (1) the positive baked contact test carried out for the "Catoctin A" rocks [Meert et al., 1994] can be extended to some degree (in terms of proving the absence of regional remagnetization) to the "Catoctin B" rocks;

[82] (2) the poles obtained for the Buckingham volcanics and Long Range dykes (Group 1) were confirmed by a baked contact test.

[83] This means that, like in the case of the Siberian data, there are grounds to interpret both directions as the primary ones. The "gamma" value for the averaged poles of Groups 1 and 2 is $55^{\circ}$. If we agree with J. Meert's assumption concerning the Late Cambrian age of the Catoctin B and other poles of Group 1, not supported by positive baked contact tests, and use merely the tested determinations available for "Buckingham Volcanics" and "Long Range Dykes", the resulting "gamma" value will be $49^{\circ}$ (Table 3 ). Note that the "Buckingham Volcanics" and "Long Range Dykes" poles are younger and older than poles of Group 2 (Table 3).

[84] Figure 17 shows that the mean pole of Group1 agrees well with the Neoproterozoic [Pisarevsky and Natapov, 2003a] and Phanerozoic [McElhinny and McFadden, 2000] APWP segments, which suggests the moderate movements and smooth drift of Laurentia (the velocity of the paleomagnetic pole drifting being about $2 \mathrm{~cm} \mathrm{year}^{-1}$ ) in the time interval of 723-535 million years. At the same time, the mean pole of Group 2 resides at a significant distance from 


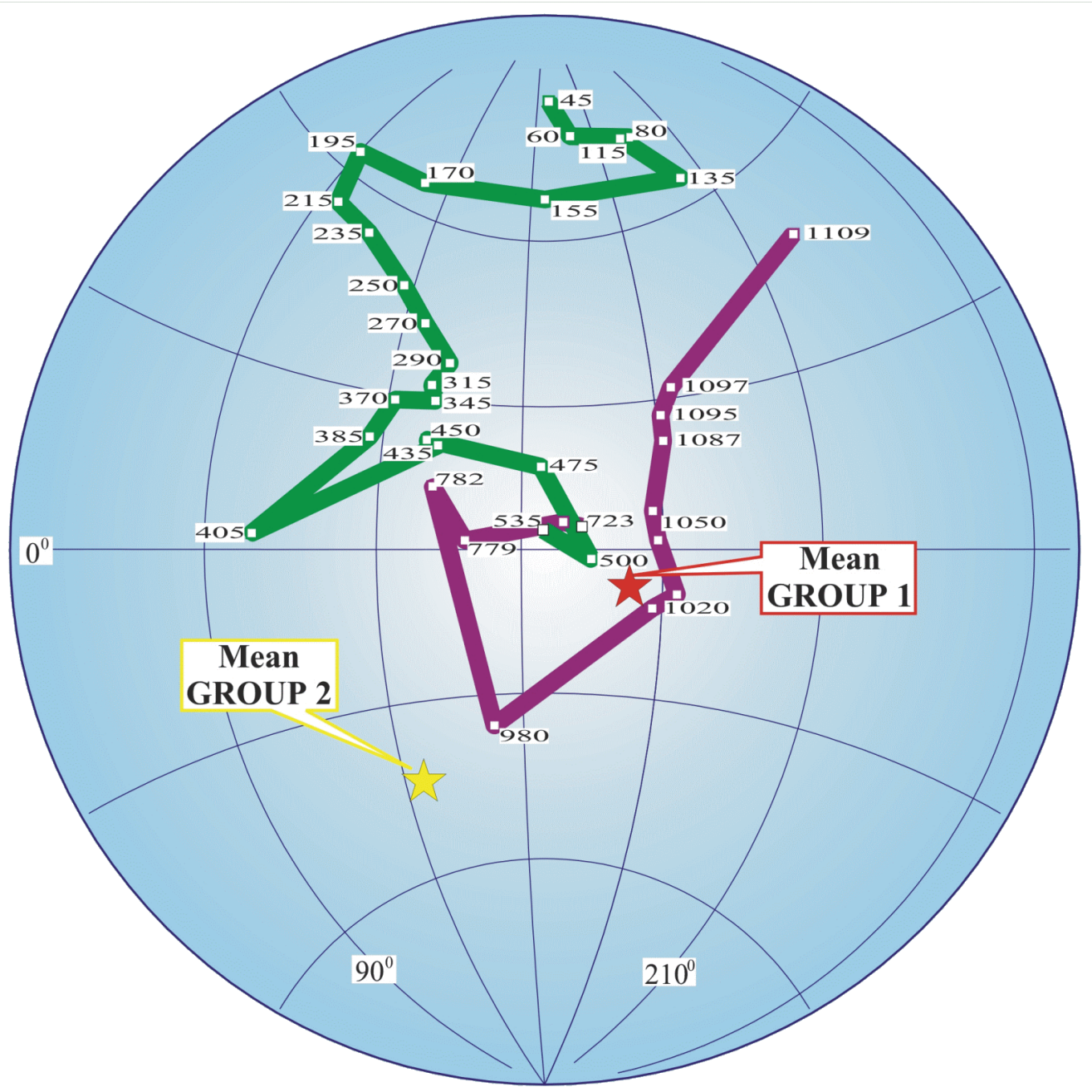

Figure 17. in Late Vendian-Lower Cambrian. of Laurentia. The Phanerozoic APWP of Laurentia is given after [McElhiny and McFadden, 2000], the Meso-Neoproterozoic one, after [Pisarevsky and Natapov, 2003].

the older and younger poles, nearest in age. This means that the choice of Version-2 as a Vendian pole complicates the APWP configuration, on one hand, and suggests the relatively higher velocities of the Laurentia paleomagnetic pole movement $\left(\sim 7 \mathrm{~cm}_{\text {year }}{ }^{-1}\right)$, on the other.

[85] Assuming the poles of groups 1 and 2 to be the true ones, reflecting the position of the Earth rotation axis, and tracing via them the Vendian APWP segment (Long Range Dykes (615 Ma) - the average of Group-2 (570 Ma) - Buckingham Volcanics ( 550 Ma)), the velocity of the merely latitudinal motion of Laurentia for the time interval of 615-550 Ma must have been about $13.5 \mathrm{~cm} \mathrm{yr}^{-1}$, which seems to be hardly probable, taking into account the data available for the modern plate movements [Kreemer et al., 2003].

[86] Therefore, proceeding from the principle of minimizing the displacements, we suggest, in accordance with our classification, to rank the poles of Group 1, as the "normal" ones, and those of Group 2, as anomalous ones.
[87] Baltica. By the present time, about 10 paleomagnetic determinations are available for the Vendian rocks of the Baltic region. They are reported in [Popov et al., 2002; Torsvik et al., 1996]. As demonstrated in the latter paper, all of the poles, except for two of them, (see Table 3 and Figure 18 in our paper) fit in the Permian-Triassic interval of the Baltic APWP [Smethurst et al., 1998b]. This fact combined with the absence of baked contact tests for these paleomagnetic determinations (all obtained using igneous rocks), as well as the regional Permian-Triassic remagnetization widespread in the Baltic territory [Shatsillo and Shipunov, 2005], allow one to date the poles as PermoTriassic. The "Winter Coast" poles [Popov et al., 2002] and those of the "Alnon Complex" [Piper, 1981] (see Figure 18 and Table 3 in this paper) reside, irrespective of the polarity choice, at considerable distances from the Baltic APWP, being, in turn, far spaced from one another, although the rocks from which they were determined have about the same age. 


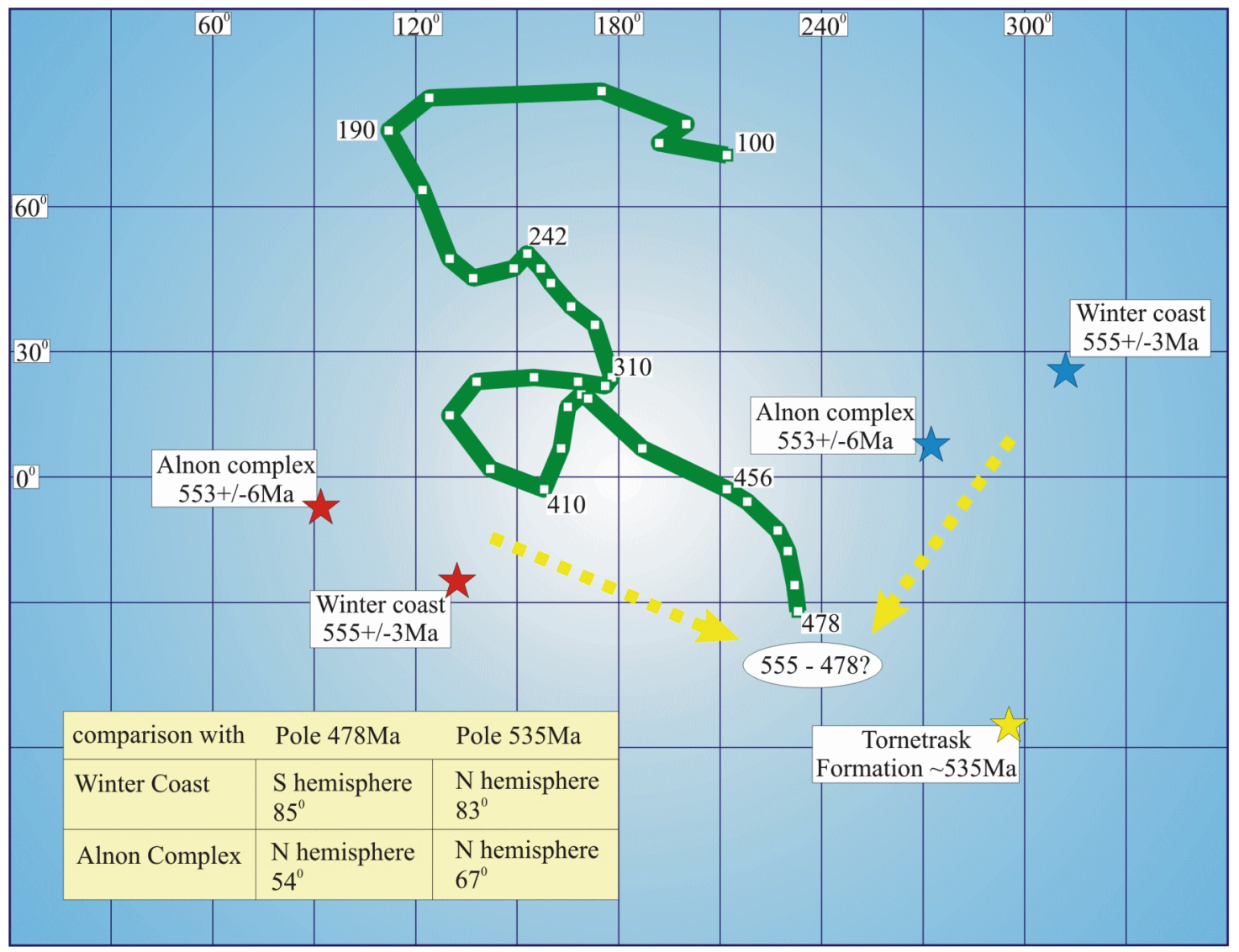

Figure 18. Model testing: Paleomagnetic poles of the Vendian and Lower Cambrian rocks of the Baltic region, compared with the Ordovician and Early Cambrian poles. The Phanerozoic APWP of the Baltic region is given after [Smethurst et al., 1998b].

[88] The "gamma" value for the "Winter Coast" and "Alnon Complex" rocks was found to be $42^{\circ}$ (see Table 3 ). Still somewhat problematic is the determination of the polarities of these poles since the most substantiated postVendian pole being the Early Ordovician one [Smethurst et al., 1998b].

[89] The recently reported data [Torsvik and Rehnstrom, 2001], obtained for the Lower Cambrian sedimentary rocks of Sweden (Tornetrask Formation), have not been confirmed by field tests, corresponding pole being close to the Triassic APWP segment of the Baltic region. Comparing the Vendian poles both with the Early Ordovician ones and with the Cambrian (?) pole derived using the Tornetrask Formation [Torsvik and Rehnstrom, 2001], taking into account the principle of the minimization of movements, the "Alnon Complex" (see inset in Figure 18) should be chosen as a "normal" pole (see inset in Figure 18). However, if the "Tornetrask Formation" pole is the result of remagnetization, then between the Vendian poles and the Early Ordovician basement of the Baltic APWP, we have a window of 80 million years, this making the use of principle of minimizing the movements to be significantly conventional. In other words, the identification of the "Alnon Complex" and
"Winter Coast" as the "normal" and "anomalous" poles, respectively, looks to be premature.

[90] As follows from Table 3, the "gamma" values for Laurentia, Baltica, and Siberia are in good agreement and coincide, within a confidence interval, indicating that our model is supported by fairly strong factual data.

\section{Conclusion}

[91] The Upper Vendian sedimentary rocks of the southwestern Siberian Platform contain two primary or nearly primary discordant paleomagnetic directions, with angle between them being $\sim 45^{\circ}$. The analysis of the paleomagnetic data available for the Vendian-Early Cambrian time suggests that the existence of two discordant directions can be considered as a phenomenon of planetary scale. This fact can be attributed to the anomalous behavior of the Earth's magnetic field in that period of time. In this paper we suggest a work model describing the "geometry" of the Earth magnetic field during the Vendian-Early Cambrian period of time, which allows one to explain the observed character of 
Table 3. The competing Vendian paleomagnetic poles of Laurentia, Baltica, and Siberia

\begin{tabular}{|c|c|c|c|c|c|c|}
\hline Pole name & Age & Pole latitude & Pole longitude & $\mathrm{A}_{95}$ & gamma & Reference \\
\hline \multicolumn{7}{|l|}{ LAURENTIA } \\
\hline \multicolumn{7}{|l|}{ Group 1} \\
\hline $\begin{array}{l}\text { 1. Johnnie Formation } \\
\text { 2. Unicoi Basalts } \\
\text { 3. Catoctin Basalts B } \\
\text { 4. Buckingam Volcanics } \\
\text { 5. Double Mer Formation } \\
\text { 6. Long Range Dykes }\end{array}$ & $\begin{array}{l}\sim 550 \\
\sim 550 \\
564 \pm 9 \\
\sim 550 \\
\sim 550 \\
615 \pm 2\end{array}$ & $\begin{array}{r}-10.0 \\
-0.4 \\
-3.8 \\
-9.5 \\
-13.7 \\
-11.6\end{array}$ & $\begin{array}{l}162.0 \\
178.6 \\
183.7 \\
160.8 \\
176.2 \\
166.0\end{array}$ & $\begin{array}{r}10.0 \\
13.8 \\
13.0 \\
7.3 \\
11.7 \\
18.0\end{array}$ & & $\begin{array}{l}{[\text { Van Alstine and Gillett, } 1979]} \\
{[\text { Brown and Van der Voo, } 1982]} \\
{[\text { Meert et al., 1994] }} \\
{[\text { Dankers and Lapointe, } 1981]} \\
{[\text { Murthy et al., 1992] }} \\
{[\text { Murthy et al., 1992] }}\end{array}$ \\
\hline \multicolumn{7}{|l|}{ Group 2} \\
\hline $\begin{array}{l}\text { Callander Complex } \\
\text { Catoctin Basalts A } \\
\text { Sept Iles Complex B }\end{array}$ & $\begin{array}{l}575 \pm 5 \\
564 \pm 9 \\
564 \pm 4\end{array}$ & $\begin{array}{l}-46.3 \\
-42.0 \\
-44.0\end{array}$ & $\begin{array}{l}121.4 \\
116.7 \\
134.5\end{array}$ & $\begin{array}{l}3.1 \\
9.0 \\
5.1\end{array}$ & & $\begin{array}{l}{[\text { Symons and Chiasson, } 1991]} \\
{[\text { Meert et al. }, 1994]} \\
{[\text { Tanczyk et al., } 1987]}\end{array}$ \\
\hline $\begin{array}{l}\text { Mean Group } 1 \text { (all) } \\
\text { Mean Group } 1(4+6) \\
\text { Mean Group } 2\end{array}$ & & $\begin{array}{r}-7.9 \\
-10.6 \\
-44.4\end{array}$ & $\begin{array}{l}173.1 \\
163.4 \\
124.1\end{array}$ & $\begin{array}{r}8.9 \\
12.1 \\
10.7\end{array}$ & $\begin{array}{l}54.5 \pm 13.5 \\
47.8 \pm 12.7\end{array}$ & \\
\hline \multicolumn{7}{|l|}{ BALTICA } \\
\hline $\begin{array}{l}\text { Winter Coast } \\
\text { Alnon Complex }\end{array}$ & $\begin{array}{l}555 \pm 3 \\
553 \pm 6\end{array}$ & $\begin{array}{r}-25.3 \\
-7.6\end{array}$ & $\begin{array}{r}132.2 \\
92.0\end{array}$ & $\begin{array}{l}3.0 \\
9.3\end{array}$ & $42.2 \pm 7.8$ & $\begin{array}{l}{[\text { Popov et al., 2002] }} \\
{[\text { Piper, } 1981]}\end{array}$ \\
\hline \multicolumn{7}{|l|}{ SIBERIA } \\
\hline $\begin{array}{l}\text { Pribaykalye and } \\
\text { Prisayanye sediments } \\
\text { Mean B1 }\end{array}$ & $545-530$ & -60.8 & 116.1 & 6.7 & $44.6 \pm 10.3$ & This study \\
\hline $\begin{array}{l}\text { Pribaykalye and } \\
\text { Prisayanye sediments } \\
\text { Mean B2 }\end{array}$ & $545-530$ & -31.6 & 63.8 & 9.8 & & $\begin{array}{l}\text { This study; } \\
\text { [Kravchinsky et al, 2001] }\end{array}$ \\
\hline \multicolumn{7}{|c|}{ MEAN GAMMA $=47.1\left(44.9^{\circ}\right)$} \\
\hline
\end{tabular}

the paleomagnetic record. Proceeding from this model, one of the directions can be ranked as a normal one, reflecting the position of the geographic pole, the other, as an anomalous one, discordant with the axis of the Earth rotation.

[92] Our results contradict the interpretation of the paleomagnetic data obtained earlier by Kirschvink and Rozanov, [1984] on Lower Cambrian of the Siberian platform as proving the hypothesis of the Inertial Interchange True Polar Wander [Kirschvink et al., 1997], our model being an alternative relative to this hypothesis.

[93] Acknowledgments. We are grateful to E. V. Sklyarov, A. M. Mazukabzov, A. M. Stanevich, D. P. Gladkochub, and T. V. Donskaya (Institute of the Earth Crust, Irkutsk) for their help in our field work; to I. V. Korovnikov and B. B. Kochnev, (Institute of Oil and Gas Geology, Siberian Branch, Russian Academy of Science, Novosibirsk) for their comprehensive and numerous consultations on the stratigraphy of the region; our special thanks are due to S. V. Shipunov (VSEGEI, St. Petersburg) for his human concern, permission to use the laboratory in- struments of this institute, as well as for his technical criticism and recommendations at the stage of rock sample preparation and the interpretation of the results. We would like to thank D. M. Pechersky for a number of helpful suggestions to improve the original manuscript. This work was supported by INTAS, project no. 03-51-5807, by the Russian Foundation for Basic Research, grants no. 04-05-65024 and 02-05-64332 and by the Programm for the Basic Researches of the Earth Science Departement of RAS "Geodynamic evolution of lithosphere of the Central Asian mobil belt (from ocean to continent)".

\section{References}

Aleksandrov, B. K., V. I. Sizykh, A. A. Bukharov, and V. D. Man (2001), New data for the nappe structure of the Baikal Range, Dokl. Akad. Nauk, 380(4), 511.

Anisimova, Z. M., and T. N. Titorenko (1976), Radiological data for the boundary layers of the Late Precambrian and 
Cambrian rocks in the folded margins of the Siberian Platform, Geol. Geofiz. (in Russian), 17(5), 107.

Bazhenov, M. L., and S. V. Shipunov (1991), Fold test in paleomagnetism: New approaches and reappraisal of data, Earth Planet. Sci. Lett., 104, 16.

Brasier, M. D., J. Cowie, and M. Taylor (1994), Decision on the Precambrian-Cambrian boundary stratotype, Episodes, $17(1-2), 3$.

Brown, P. M., and R. Van der Voo (1982), Paleomagnetism of the latest Precambrian/Cambrian Unicoi basalts from the Blue Ridge, northeast Tennessee and southwest Virginia: evidence for Taconic deformation, Earth Planet. Sci. Lett., 60, 407.

Dankers, P., and P. Lapointe (1981), Paleomagnetism of Lower Cambrian volcanics and a cross-cutting Cambro-Ordovician diabase dyke from Buckingham (Quebec), Can. J. Earth Sci., 18, 1174 .

Enkin, R. J. (1994), A Computer Program Package for the Analysis and Presentation of Paleomagnetic Data, 16 pp., Pacific Geoscience Center, Geological Survey of Canada.

Enkin, R. J. (1990), Formation et Deformation de l'Asie depuis la Fin de l'Ere Primaire, 120 pp., These de Doctorat de l'Universite, Paris 7.

Gallet, Y., V. Pavlov, and V. Courtillot (2003), Magnetic reversal frequency and apparent polar wander of the Siberian platform in the earliest Palaeozoic, inferred from the Khorbusuonka river section (northeastern Siberia), Geophys. J. Int., 154, 829.

Gurevich, E. L. (1981), Paleomagnetism of Late Precambrian rocks in the Irkutsk Amphitheater: Problems of their correlation and paleogeographic positions, in Paleomagnetism and Problems of Paleogeography, p. 11, VNIGRI, Leningrad.

Gurevich, E. L. (1983), Paleomagnetic studies of Precambrian rocks in the north of the Siberian Platform, in Paleomagnetism of Late Precambrian Rocks in the USSR Territory, p. 39, VNIGRI, Leningrad.

Harland, W. B., R. L. Armstrong, A. V. Cox, L. E. Craig, A. G. Smith, and D. G. Smith (1990), Geologic Time Scale 1989, 263 pp., Cambridge University Press, Cambridge.

Khomentovsky, V. V. (2000), The geochronological substantiation of the Vendian-Early Cambrian Scale by U-Pb datings using zircons, Geology and Geophysics, 41(4), 503.

Khomentovsky, V. V., and A. A. Postnikov (2001), Neoproterozoic formation history of the Baikal-Vilyui branch of the Paleoasian Ocean, Geotectonics (in Russian), 35(3), 3.

Khomentovsky, V. V., M. Sh. Faizullin, and G. A. Karlova (1998), The Nemakit-Daldynian Stage of the Vendian rocks in the southwest of Siberian Platform, Dokl. Akad. Nauk, 362(6), 813 .

Khomentovsky, V. V., B. Yu. Shenfil, M. S. Yakshin, and E. T. Butakov (1972), The Marker Sequences of Late Precambrian and Early Cambrian Rocks in the Siberian Platform, 355 pp., Nauka, Moscow.

Kirschvink, J. L., and A. J. Rozanov (1984), Magnetostratigraphy of Lower Cambrian strata from the Siberian Platform: Paleomagnetic pole and preliminary polarity time-scale, Geol. Mag., 121(3), 189.

Kirschvink, J. L., R. L. Ripperdan, and D. A. Evans (1997), Evidence for a large-scale reorganization of Early Cambrian continental rock masses by the inertial interchange of True Polar Wander, Science, 277, 541.

Komissarova, R. A. (1991), Paleomagnetism of Precambrian rocks in the northern and eastern surroundings of the Siberian Platform, in Paleomagnetism and Geodynamics of the USSR territory, p. 83, VNIGRI, Leningrad.

Komissarova, R. A. (1983), Paleomagnetism of Riphean and Vendian sedimentary rocks in the area west of the Baikal Lake, in Paleomagnetism of Late Precambrian rocks in the USSR, p. 52, VNIGRI, Leningrad.

Komissarova, R. A. (1984), Results of the paleomagnetic study of Late Precambrian rocks in the Belaya $\mathrm{R}$. area (the northern part of the Yudoma-Maya Trough), in Paleomagnetic Methods In Stratigraphy, p. 8, VNIGRI, Leningrad.

Komissarova, R. A., and E. P. Osipova (1986), Results of the paleomagnetic study of the Middle Riphean to Cambrian rocks in the Maya River area, in Magnetic Stratigraphy and Paleomagnetism of Sedimentary and Volcanic Rocks in the USSR, p. 5, VNIGRI, Leningrad.

Konstantinov, K. M. (1998), A Dynamic Physicogeological Model of the Baikal Folded Area from Paleomagnetic Data, Cand. Sci. Dissertation, p. 18, Author's Abstract, Irkutsk.

Korolyuk, I. K., and A. D. Sidorov (1969), Stromatolites from the Moty Series rocks of the South Baikal and Southwest Sayan regions, Dokl. Acad. Nauk SSSR, 184(3), 669.

Kochnev, B. B. (2002), Stratigraphy of Vendian Rocks in the Southwest of the Siberian Platform, Candidate Sci. Dissertation, Author's Abstract, Novosibirsk.

Kravchinsky, V. A., K. M. Konstantinov, and J. P. Cogne (2001), Paleomagnetic study of Vendian and Early Cambrian rocks of South Siberia and Central Mongolia: Was the Siberian Platform assembled at that time?, Precambrian Res., 110, 61.

Kreemer, C., W. E. Holt, and A. J. Haines (2003), An integrated global model of present-day plate motions and plate boundary deformation, Geophys. J. Int., 154, 8.

Landing, E. (1994), Precambrian-Cambrian boundary global stratotype ratified and new perspective of Cambrian time, Geology, 2, 179 .

Letnikova, E. F., A. B. Kuznetsov, and S. V. Veshcheva (2004), Results of the geochemical and isotopic studies of the Baikal Series rocks: Agreements and disagreements with biostratigraphic and geohistorical data, in The Geodynamic Ocean-toContinent Evolution of the Lithosphere in the Mobile Belt of Central Asia, p. 18, published by the Institute of Geology, Siberian Division, Russ. Akad. Nauk, vol. 2, Irkutsk.

Malykh, A. V. (1997), The comparative analysis and genesis of the fold structures of the eastern part of Irkutsk amphitheatre, Geotectonics (in Russian), 31(2), 28.

McElhinny, M. W., and P. L. McFadden (2000), Paleomagnetism: Continents and Oceans, 386 pp., Academic Press, San Diego.

Meert, J. (1999), A paleomagnetic analysis of Cambrian true polar wander, Earth Planet. Sci. Lett., 168, 131.

Meert, J. G., and R. Van der Voo (2001), Comment: New paleomagnetic result from Vendian red sediments in Cisbaikalia and the problem of the relationship of Siberia and Laurentia in the Vendian by S. A. Pisarevsky, R. A. Komissarova and A. N. Khramov, Geophys. J. Int., 146, 867.

Meert, J. G., R. Van der Voo, and T. Payne (1994), Paleomagnetism of the Catoctin volcanic province: a new VendianCambrian apparent polar wander path for North America, $J$. Geophys. Res., 99((B3)), 4625.

Murthy, G. S., C. Gower, M. Tubett, and R. Patzold (1992), Paleomagnetism of Eocambrian Long Range dykes and Double Mer Formation from Labrador, Canada, Can. J. Earth Sci., 29, 1224.

Pavlov, V. E., and P. Yu. Petrov (1997), The paleomagnetism of Riphean rocks in the Irkineeva High of the Enisei Range: A new argument in favor of the unity of the Siberian Platform in Middle Riphean time, Phys. Solid Earth, 33(6), 42.

Pavlov, V., and Y. Gallet (1998), Upper Cambrian to Middle Ordovician magnetostratigraphy from the Kulumbe River section (Northwestern Siberia), Phys. Earth Planet. Inter., 108, 49.

Pavlov, V. E., Y. Gallet, and V. Courtillot (2003), Geomagnetic reversal frequency and the apparent polar wander of the Siberian Platform in the earliest Paleozoic: Inferred from the Khorbusuonka River section (NE Siberia), Geophys. J. Int., 154,829 .

Pavlov, V. E., I. Galle, A. V. Shatsillo, and V. Yu. Vodovozov (2004), Early Cambrian paleomagnetism in the valley of the lower Lena R. course: New constraints for the curve of apparent pole migration in the Siberian Platform and the anomalous behavior of the geomagnetic field at the beginning of the Phanerozoic, Phys. Solid Earth, 40(2), 28.

Piper, J. D. A. (1981), Magnetic properties of the Alnon Complex, Geol. Foeren. Stockholm Foerh., 103, 9.

Pisarevsky, S. A., and L. M. Natapov (2003a), Siberia in Rodinia, Tectonophysics, 375, 221. 
Pisarevsky, S. A., and M. E. McElhinny (2003b), Global Paleomagnetic visual data base developed into its visual form, EOS, 84(20), 45.

Pisarevsky, S., E. Gurevich, and A. Khramov (1997), Paleomagnetism of the Lower Cambrian sediments in the Olenek River area (N Siberia): Paleopoles and the problem of the magnetic polarity in the Early Cambrian, Geophys. J. Int., 154, 829.

Pisarevsky, S. A., R. A. Komissarova, and A. N. Khramov (2000), New paleomagnetic results from the Vendian red sediments in Cisbaikalia and the problem of a relationship between Siberia and Laurentia in the Vendian time, Geophys. J. Int., 140, 598.

Pisarevsky, S. A., R. A. Komissarova, and A. N. Khramov (2001), Reply to comment by J. G. Meert and R. Van der Voo on "New palaeomagnetic result from Vendian red sediments in Cisbaikalia and the problem of the relationship of Siberia and Laurentia in the Vendian", Geophys. J. Int., 146, 871.

Popov, V. V., A. G. Iosifidi, A. N. Khramov, J. Tait, and V. Bachtadse (2002), Paleomagnetism of Upper Vendian sediments from the Winter Coast, White Sea region, Russia: Implications for the paleogeography of Baltica during Neoproterozoic times, J. Geophys. Res., 107(B11), 2315.

Psarchik, Ya. K. (1963), The lithology and facies of the Lower and Middle Cambrian deposits in the Irkutsk Amphitheater in terms of their oil and salt contents, Proc. VSEGEI, 89, 396.

Rodionov, V. P. (1984), Paleomagnetic study of Late Precambrian and Early Paleozoic rocks in the Udzha River area, in Paleomagnetic Methods in Stratigraphy, p. 18, VNIGRI Proc., Leningrad.

Rozanov, A. Yu., L. N. Repina, and M. K. Appolonov (1992), The Cambrian of Siberia, 135 pp., Nauka, Siberian Div..

Rozanov, A. Yu., M. A. Semikhatov, B. S. Sokolov, and V. V. Khomentovsky (1997), A choice of a stratotype for the Precambrian and Cambrian boundary: A breakthrough or an error?, Stratigraphy, Geol. Correlation (in Russian), 5(1), 21.

Rozen, O. M., and V. S. Fedorovsky (2001), Collision Granitoids and the Layering of the Earth Crust, 188 pp. Nauchnyi Mir, Moscow.

Sovetov, Yu. K. (2002a), Vendian glaciation of the Siberian Craton, in Geology, Geochemistry, and Geophysics at the Boundary of the $X X$ and $X X I$ Centuries, p. 21, IEC, Irkutsk.

Sovetov, Yu. K. (2002b), Comparison of the geodynamic histories of the Siberian and East European Cratons in Vendian time from the results of analyzing their foreland basins, in Geology, Geochemistry, and Geophysics at the Boundary between the $X X$ and XXI centuries, p. 120, IEC, Irkutsk.

Sokolov, B. S. (1975), New fossils found in the Preusolian rocks of the Irkutsk Amphitheater, in The Analogs of Vendian Rocks in Siberia, p. 112, Nauka, Moscow.

Sokolov, B. S. (1997), Essays on Vendian Rock Accumulation, 156 pp., KMK Press, Moscow.
Shatsillo, A. V., and S. V. Shipunov (2005), The principles of construction of apparent polar wander parths, 56 pp., Nauka, Moscow.

Shatsillo, A. V., A. N. Didenko, and L. Z. Reznitskii (2001), The Vendian paleomagnetic trends of the Siberian Platform and the problem of agreement between the Paleozoic and Riphean trends of the apparent magnetic pole: A new paleomagnetic determination for the Vendian rocks of the Sayan region, in Paleomagnetism and Magnetism of Rocks, p. 88, United Research Institute of the Earth Physics, Moscow.

Shipunov, S. V. (1995), A new fold test in paleomagnetism: Rehabilitation of an equalizing test, Phys. Solid Earth, 31(4), 67.

Shipunov, S. V., and A. A. Muraviev (2000), The sensitivity and reliability of a fold test in paleomagnetism, Phys. Solid Earth, 36(7), 10

Smethurst, M. A., A. N. Khramov, and T. N. Torsvik (1998a), Neoproterozoic and Paleozoic data for Siberian Platform: from Rodinia to Pangea, Earth Sci. Rev., 43, 1.

Smethurst, M. A., A. N. Khramov, and S. A. Pisarevsky (1998b), Palaeomagnetism of the Lower Ordovician Orthoceras Limestone, St. Petersburg, and a revised drift history for Baltica in the early Palaeozoic, Geophys. J. Int., 133, 44.

Symons, D. T. A., and A. D. Chiasson (1991), Paleomagnetism of the Callander Complex and the Cambrian apparent polar wander path for North America, Can. J. Earth Sci., 28, 355.

Tanczyk, E. I., P. Lapointe, W. A. Morris, and P. W. Schmidt (1987), A paleomagnetic study of the layered mafic intrusion at Sept-Iles, Quebec, Can. J. Earth Sci., 24, 1431.

Torsvik, T. H., J. G. Meert, and M. A. Smethurst (1998), Polar wander and the Cambrian, Science, 279, 9a.

Torsvik, T. H., M. A. Smethurst, J. G. Meert, V. R. Van, d, W. S. McKerrow, M. D. Brasier, B. A. Sturt, and H. J. Walderhaug (1996), Continental breakup and collision in the Neoproterozoic and Palaeozoic: A tale of Baltica and Laurentia, Earth Sci. Rev., 40, 229.

Torsvik, T. H., and E. F. Rehnstrom (2001), Cambrian paleomagnetic data from Baltica: implications for true polar wander and Cambrian paleogeography, J. Geol. Soc. London, 158, 321.

Tucker, R. D., and W. S. McKerrow (1995), Early Paleozoic chronology: A review in the light of new U-Pb zircon ages from Newfoundland and Britain, Can. J. Earth Sci., 32, 368.

Van Alstine, D. R., and S. L. Gillett (1979), Paleomagnetism of Upper Precambrian sedimentary rocks from the Desert Range, Nevada, J. Geophys. Res., 84, 4490.

A. N. Didenko, Geological Institute, Russian Academy of Science, 7 Pyzhevskii per., Moscow, 119017 Russia

A. V. Shatsillo, V. E. Pavlov, Institute of Physics of the Earth, Russian Academy of Science, 10 Bol'shaya Gruzinskaya ul., Moscow, 123995 Russia 